\title{
Geophysical Contribution to the Determination of the Limit between Laayoune and Foum El Oued Aquifers, Origin of Supply Sources of Oued Sakia El Hamra, Laayoune Province, Morocco
}

\author{
Mohamed Chibout1, Anasse Benslimane1, Mohamed El Mokhtar², Fatima Zahra Faqihi1, \\ Sidi Mokhtar El Kanti³, Ahmed Ntarmouchant1
}

\author{
${ }^{1}$ Laboratory of Geodynamics and Natural Resources (LGRN), Faculty of Sciences Dhar Mahraz, Sidi Mohamed Ben Abdellah \\ University, Fez, Morocco \\ ${ }^{2}$ Laboratory of Geosciences and Natural Resources, Faculty of Sciences, University Ibn Tofail, Kenitra, Morocco. \\ AFRICA GEO-SERVICES Company, 33 Offices Al Manar Street Abd Elkarim Khattabi, Fez, VN, Morocco \\ ${ }^{3}$ Hydraulic Basin Agency of Sakia El Hamra and Oued Ed-Dahab, Administrative District, Laayoune, Morocco \\ Email: medsaid@yahoo.com
}

How to cite this paper: Chibout, M., Benslimane, A., El Mokhtar, M., Faqihi, F.Z., El Kanti, S.M. and Ntarmouchant, A. (2019) Geophysical Contribution to the Determination of the Limit between Laayoune and Foum El Oued Aquifers, Origin of Supply Sources of Oued Sakia El Hamra, Laayoune Province, Morocco. International Journal of Geosciences, 10, 1008-1035. https://doi.org/10.4236/ijg.2019.1011058

Received: October 8, 2019

Accepted: November 26, 2019

Published: November 29, 2019

Copyright $\odot 2019$ by author(s) and Scientific Research Publishing Inc. This work is licensed under the Creative Commons Attribution International License (CC BY 4.0).

http://creativecommons.org/licenses/by/4.0/

\section{c) (i) Open Access}

\begin{abstract}
Laayoune and the Foum El Oued aquifers are in hydraulic communication only at the level of Oued Saguia El Hamra. The present study has accordingly made use of all the hydrogeological, hydrological, geological and geophysical data that preceded the watershed of Oued Saguia El Hamra in its downstream part. These data are by no means omplementary with the objective of having a better understanding of the boundary line between Laayoune and Foum El Oued aquifers and the origin of feeding the sources of Oued Saguia El Hamra. This study will focus only on the previous geophysical studies where a reinterpretation of electrical soundings has proved useful as a result of the recent well-logging results. It makes it possible to highlight the presence of a significant rise in the truncated marly substratum of Oued Saguia El Hamra and depressions (left and right banks) which could correspond to stream channels or depressed areas. At the level of the Wadi bed, there has been a regular immersion of the conductive level roofs from east to west towards Foum El Oued favoring the flow of wastewater from the zone and spraying the brackish water sources towards the groundwater of Foum El Oued. In the light of the reinterpretation of electric polls, plus as well as the geophysical surveys by electrical tomography and high definition made at the right and left banks of the Oueed Saguia El-Hamra, it was possible to verify the existence of dry
\end{abstract}


ridge separating the two webs of Laâyoune and Foum El Oued and stream channels or depressed areas of the left bank for drainage of brackish water to sources located along Oued Saguia El Hamra. The true resistivity models tomography profiles confirm the presence of the backbone at the left and right banks and the graben of the left bank for underground water drainage of the web Laayoune to sources welling the river Saguia El Hamra. They reveal the presence of a quaternary plio-cover (coastal platform Moghrebian) as being heterogeneous and affected by many electrical discontinuities, particularly in the level resistant R2 (coquina sandstone). These discontinuities could correspond to lateral changes in facies and/or synsedimental faults compartmentalizing the plio-quaternary formations into a system of Horsts and Grabens that relies on the whole (D1, Cs) attributed to formations from the Miocene to the Upper Cretaceous. The contours of the map show the distribution of the three families of electrical soundings A, B and C limited by two main electrical discontinuities D and $\mathrm{M}$. East of discontinuity million, this map reflects the look of the wall of the Pliocene-Quaternary resting on the impermeable upper Cretaceous floor. To the west of this electrical discontinuity M, the map reflects the behavior of the roof of marl deposits of Miocene age.

\section{Keywords}

Laayoun and Faum Al Oued Aquifers, Ridge, Limit Wastewater, Brackish Water, Marl Bedrock, Vertical Electrical Sounding (SEV), Electrical

Tomography (ETR)

\section{Introduction}

Many geophysical (seismic, gravimetric, aeromagnetic and especially geoelectric), hydrological and hydrogeological studies were performed at the basin of Sakia El Hamra and Oued Eddahab (South of Morocco) [1] [2] [3] [4]. Each of these studies was developed to solve a specific problem in a well-defined area.

The majority of geophysical studies, including particularly the geoelectric (50 studies) and seismic (about $400 \mathrm{Km}$ ) aimed to map geological levels that could be potential aquifers.

In light of the results of these studies, the Regional Direction of the Hydraulic of Sahara (DRH) and subsequently the Basin Agency of Sakia El Hamra and Oued Hydraulic Eddahab (ABHSHOD), performed several drill holes, controlled by logs for the release of water resources for potable water supply, irrigation, industrial and for watering livestock [5] [6] [7].

In these previous studies, a geophysical electrical tomography was performed at the level of the left and right banks of the Oued Saguia El-Hamra with the aim of verifying the existence of the dry dorsals between Foum El Oued and the two plies Laayoune and the fluvial channels of the left and the right sides for drainage of brackish water to the sources of the river Saguia El-Hamra.

In addition to the drop in water levels, this overuse of the groundwater is ac- 
companied by the deterioration of groundwater quality following the intrusion of seawater in the aquifer of Foum El Oued and the uplift of the freshwater/salt-water (Upconing) interface of the deep salt water [8].

For a sustainable management of the underground water resources of these aquifers, namely that of Foum El Oued as the most requested in the region, this aquifer requires the update of its geometry and the determination of its limits in order to establish more reliable mathematical models. Hence, we will focus mainly on the eastern boundary between the layers of Foum El Oued and Laayoune. The understanding of this limit will allow to better define the origin of the groundwater recharge of Foum El Oued and the possible contaminations by the sewage of Laayoune city and the brackish waters of Laayoune aquifers.

The area under study, which spans the bed of Oued Saguia el Hamra and its left and right banks, is located between the spreading zone and the dunes located east of Foum El Oued (Figure 1). It is a part of the urban district of Laayoune, Laayoune province, Laayoune-Saguia El Hamra region and falls within the action area of the Hydraulic Basin of Saguia El Hamra and Oued Eddahab (ABHSHOD).

The topography of the study area is monotonous and can be summed up as a series of gently sloping plateau towards the Atlantic Ocean (Figure 1), except for the presence of the SSW-NNE-oriented dune cordon that is sometimes separated by slope failures and by small discontinuous rocky cuestas. The only reliefs observed in the area are the followings:

NNE-SSW oriontation dune cords located west of the study area;

- Flanks of the left and right banks of the Oued Saguia El Hamra, where the reliefs reach more than $60 \mathrm{~m}$ at the level of Laayoune and disappear in the area of Foum El Oued.

From a hydrological background, the main hydrographic element of the Laayoune region is represented by Oued Saguia El Hamra, and it is characterized by discontinuous flows depending on the intensity of rainfall and floods.

The study area is characterized by a warm coastal Saharan-type climate. In Laayoune region, the annual average precipitation is $44.55 \mathrm{~mm}$. The monthly average temperature varies between 17.5 (January) and $26.6^{\circ} \mathrm{C}$ (August) [3] [8].

\section{Geological and Hydrogeological Framework}

\section{a) Regional geology}

The basin under study is surrounded by four structural geological units in the Sahara:

- The Anti-Atlas massif;

- The Reguibat Ridge;

- Mauritanides;

- The Tindouf basin.

The syncline of NW Africa has developed at the boundary between the Atlantic Ocean and the stable African Shield since the recent Precambrian. To the west of the Hercynian folded central chain, a thick series of Mesozoic and 


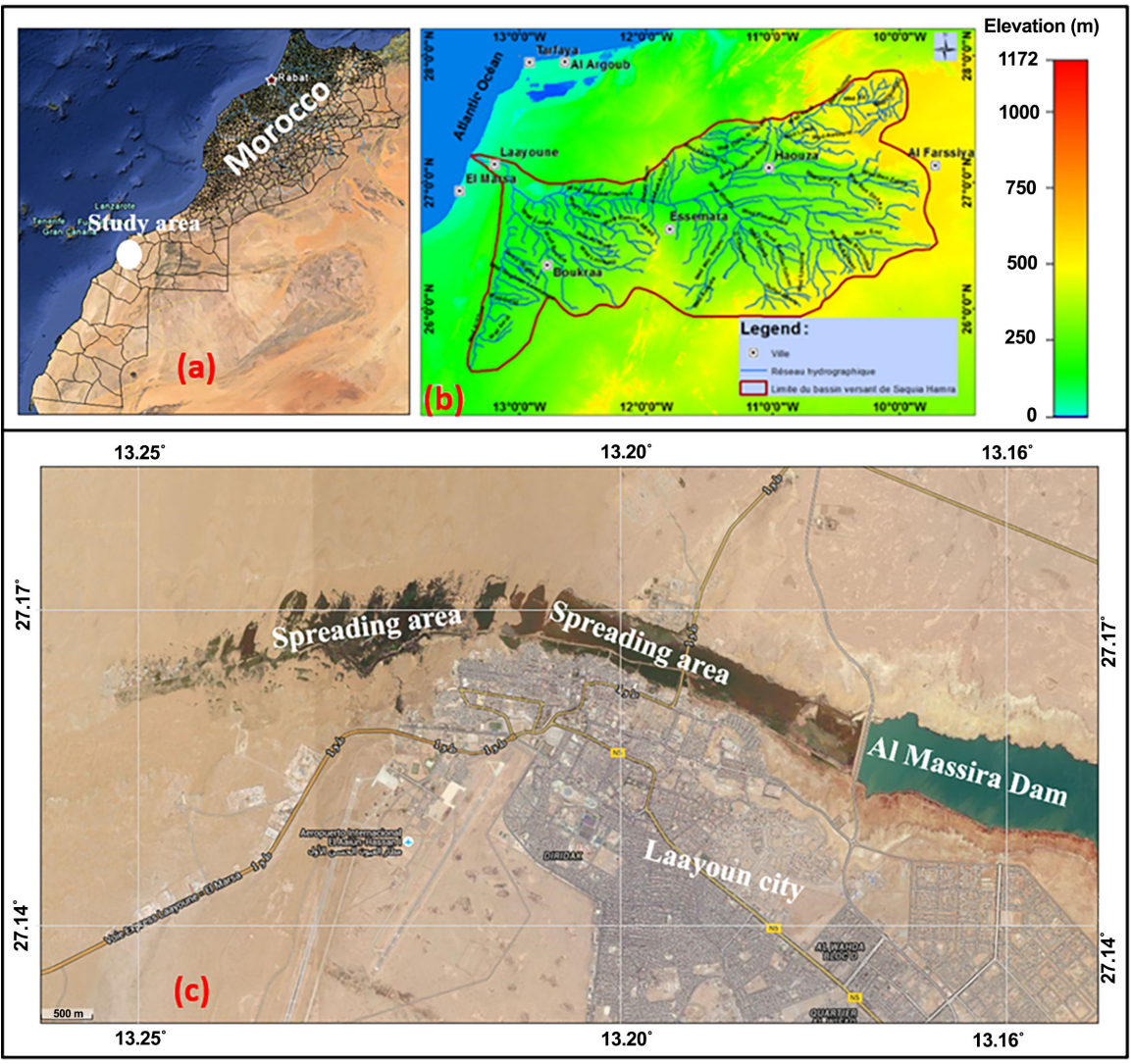

Figure 1. Location plan of the study area (a): Study area; (b): Oued Sakia Al Hamra Hydrographic Network; (c): Satellite view of the study area (Google Eaurth, MNT of Maroc).

Cenozoic sediments were deposited in the Sahara basin and rest on the Precambrian or the Paleozoic age bedrock. The maximum onshore deposit is located in the Daoura region with more than $10 \mathrm{~km}$ thick. Laayoune basin is a monoclonal shallowly dipping towards the west [9]-[13].

The highly tectonized Hercynian folded central zone is highly compressed and is overlapped to the east with anticlinal and synclinal structures elongated in the $\mathrm{N}-\mathrm{S}$ direction and clamped in the transverse direction. This is the area that separates the Tindouf basin to the east of the Laayoune basin to the west. These two basins are weakly tectonized.

From a structural background the tow major tectonic directions that control the structuring of the Laayoune basin [14] are as follows:

- Direction ENE-WSW of the Anti-Atlas and the Reguibate chain.

- Direction NNE-SSW of the North West Africa geosyncline.

Figure 2 below illustrates the regional geology of the Meso-Cenozoic basin of the Sahara and its borders.

From a stratigraphic point of view, according to the stratigraphic correlations made between the 48 oil drilling carried out in the 1960s and the Spanish geological maps at the scale of 1:200,000, the regional geology is characterized by two following cycles [15] [16] [17].

- Precambrian and primary cycle starting from Precambrian to Carboniferous. 


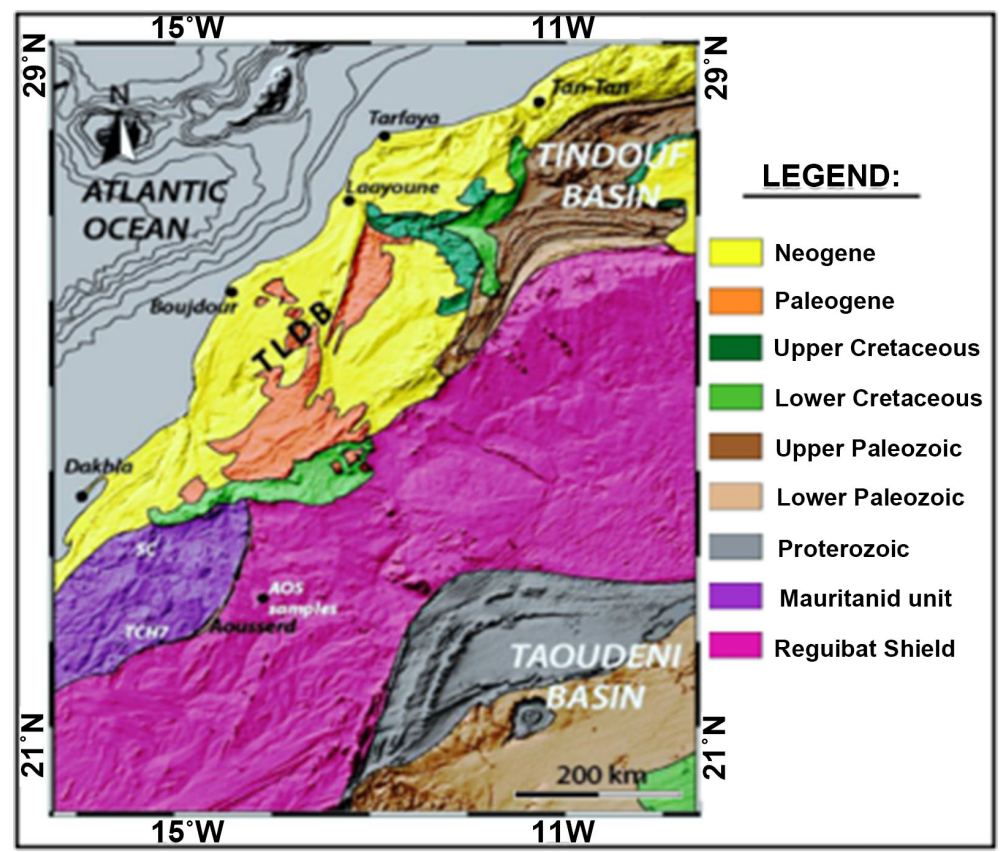

Figure 2. Geological map of Saguia El Hamra and Oued Eddahab basin [18].

- Meso-Cenozoic cycle that begins from the Triassic to the Quaternary constituting most of the filling of the Laayoune-Dakhla basin.

\section{b) Local geology}

The main geological formations outcropping in the study area are of PlioQuaternary age characterized by the presence of numerous lateral variations of facies. These formations include, in addition, the bright dunes and the terraces with alluvial deposits of Oued Saguia El Hamra (Figure 3).

The left and right banks consist of three main series:

- A limestone series starting from top to bottom with calcarenites which then tunrs bioclastic and lumachellic.

- A micro-conglomeratic sandstone series with sand passages in the center that are well developed north of the right bank and become more clayey.

- A limestone lumachellic series.

These formations are based directly on marly bedrock of Miocene to Late Cretaceous ages [19] [20] [21]. In the bed of Oued Saguia El Hamra, the formations mentioned above are eroded, up to the marl bedrock and replaced by recent alluvial deposits consisting of sands, clays, flint marls resting on gray marls plastic (cuts lithological drilling 962/120 and 963/120).

\section{c) Hydrogeology}

The main superficial aquifers formed by the Plio-Quaternary formations contain layers of the right and left banks of Laayoune and that of Foum El Oued in the West (Figure 4). Laayoune aquifer consists essentially of Pliocene lumachellic sandstones.

The right bank of the water runs in clay sand at the NNW and in the east and in the dolomitic fossiliferous limestones in the west. The average thickness of the 


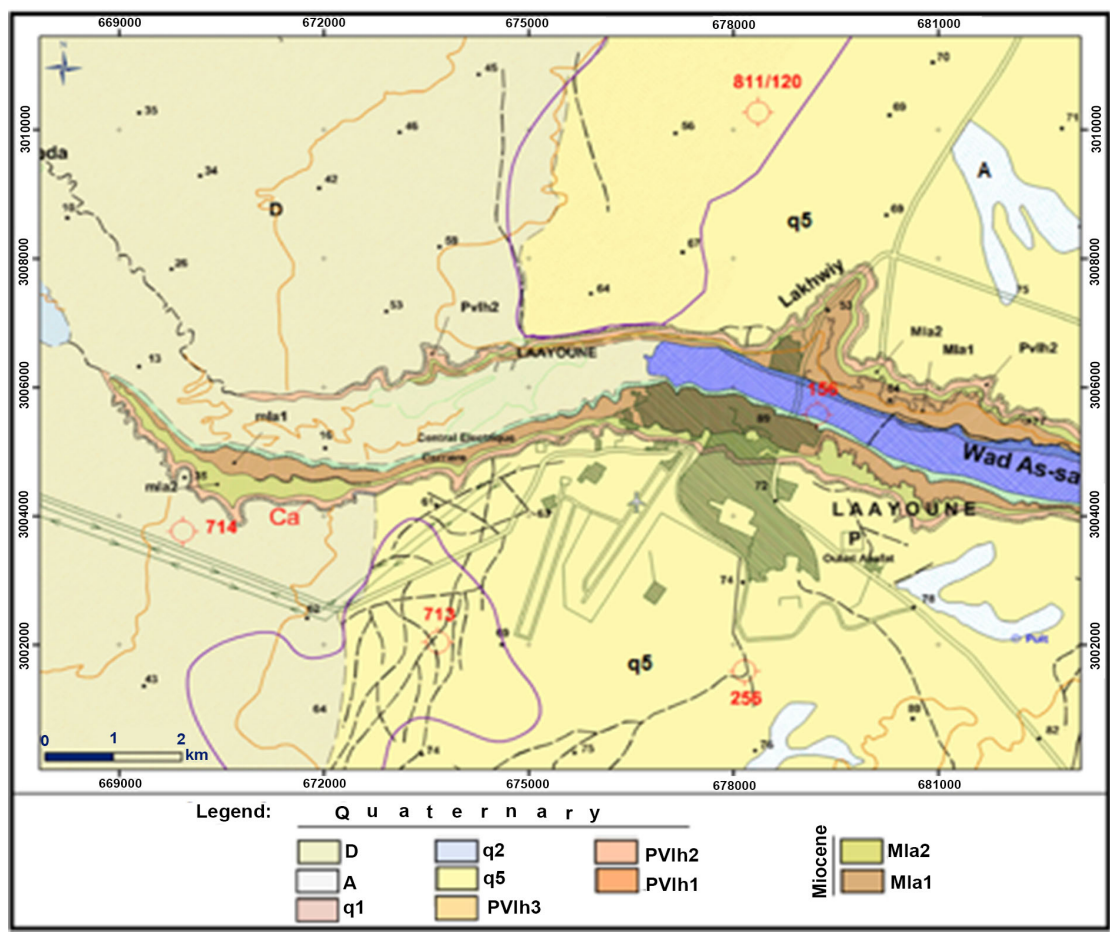

(a)

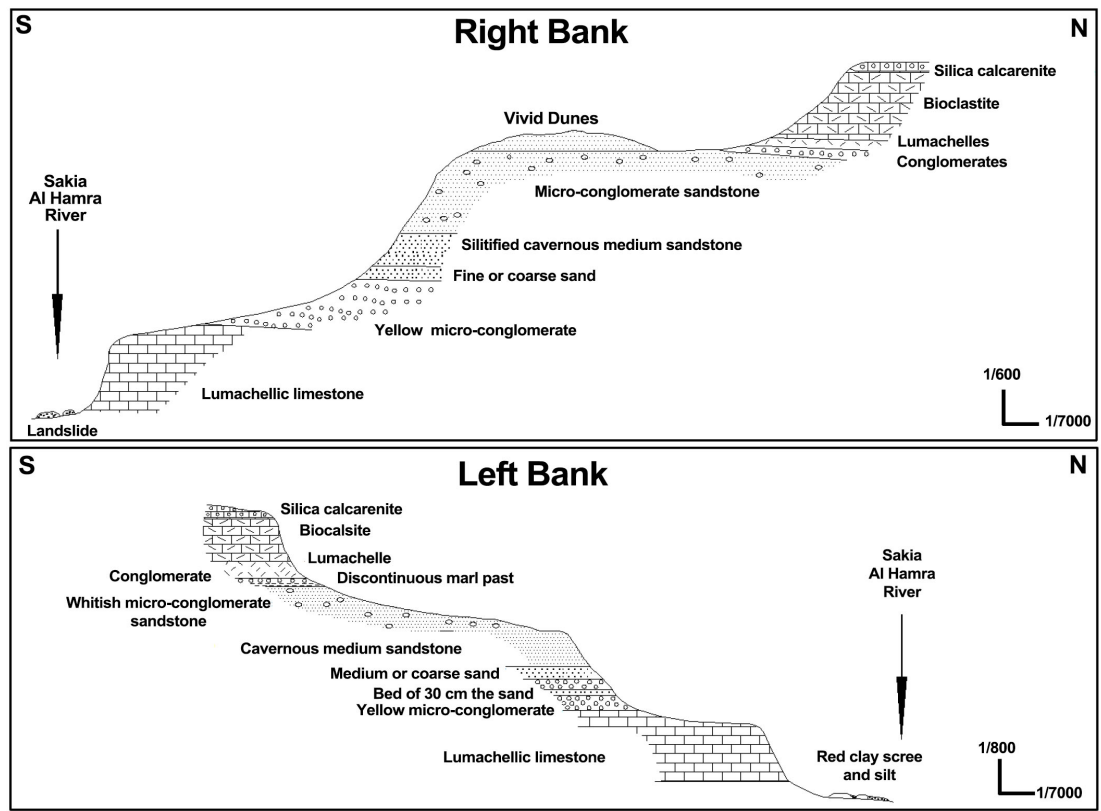

(b)

Figure 3. (a): Extract of Laâyoune geological map at 1/100,000: D: Sandhills; A: Silts and evaporates; q1: Alluvial terrace (named in the Sahara by "recent reg”); q2: Spreading loamy and stony average terrace, "old reg"; q5: Slab made of carbonated sandstone and conglomerate; PVlh3: Carbonated whitish marl; PVlh2: Clear lumachelle within shells of gastropods, Brachiopods and conglomerate in the base; PVlh1: Redhead lumachelle mainly within oyster shells and gastropods; Mla2: Whitish marl sandstone, sometimes with flint; Mla1: Lumachelle, sandy yellowish marls, sandstone, conglomerate, micro alternation of the whitish marls and the yellowish with a lumachellic bench. (b) Lithological sections of the left bank of Oued Saguia El Hamra at Laayoune [22]. 


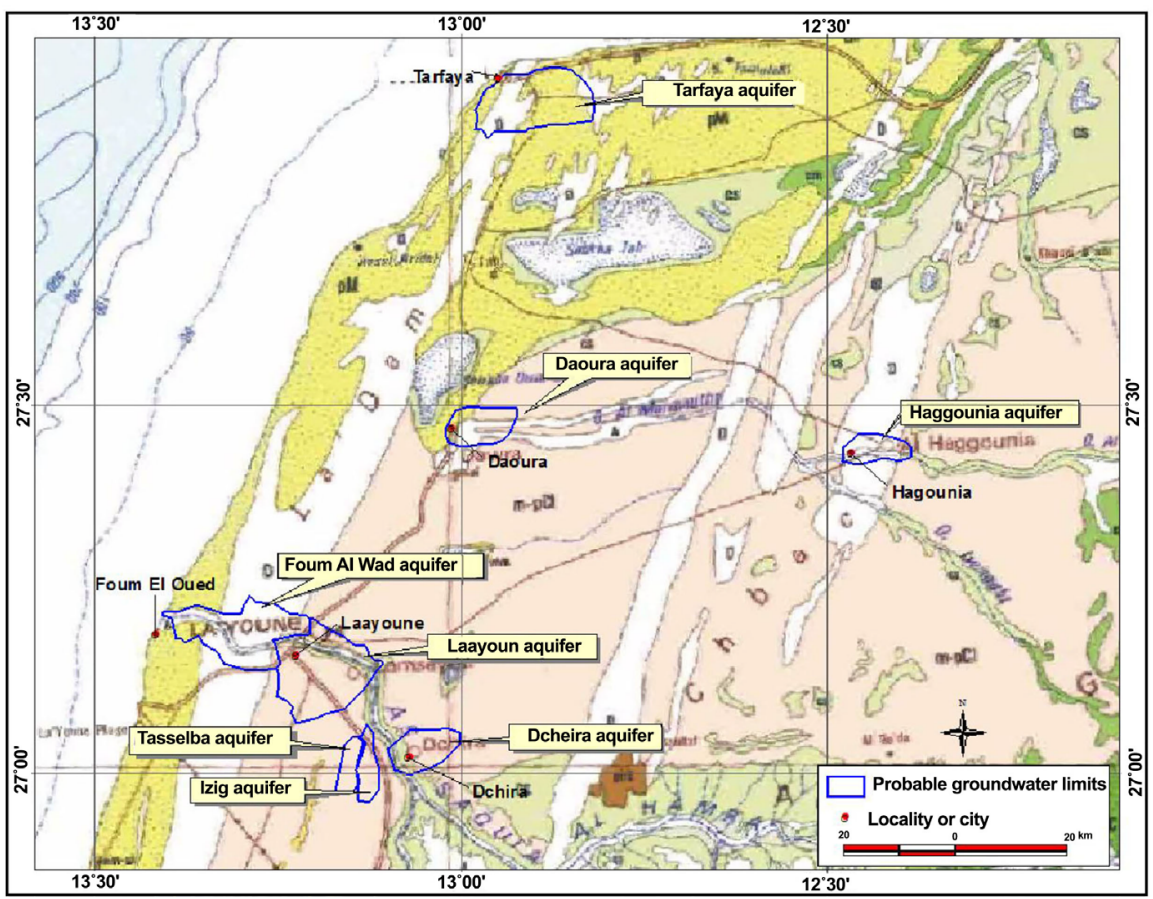

Figure 4. Groundwater situation map of Foum El Oued and Laayoune.

aquifer is of the order of $5 \mathrm{~m}$ with a water level located around $40 \mathrm{~m}$ deep. The water released from the aquifer is brackish with salinity close to $7 \mathrm{~g} / 1$ [23].

The aquifer of the left bank circulates in lumachellic limestones rests on the marly substratum. Water output is brackish with salinity ranging from $2.5 \mathrm{~g} / \mathrm{l}$ in the east to $9 \mathrm{~g} / \mathrm{l}$ in the west.

\section{Methodology}

Geophysical methods employed in this work are mainly DC geoelectrical methods based primarily on vertical electrical soundings (SEV) and electrical tomography profiles (ERT). These last two methods, known as non-destructive subsurface exploration methods, are widely used in hydrogeology and engineering geology. The aim behind adopting these geoelectric methods is to obtain the electrical resistivity expressed in ohm.m, the layers basement from the measurement of the potential difference between two reception electrodes that is generated by the circulation of the current injected at the surface by two emission electrodes. The value of the resistivity, according to [24] [25], depends mainly on the water content, the mineralization of the water, the clay content as well as the granulometry.

These geoelectric methods have been extensively described in many theses, articles and books. Among these, we cite those of [26] [27] [28].

In vertical electrical sounding (SEV), the transmitting $(\mathrm{A}, \mathrm{B})$ and receiving $(\mathrm{M}, \mathrm{N})$ electrodes are distributed in the field according to the Schlumberger device (Figure 5(a)). It is the most suitable device for geoelectric methods applied to hydrogeology, where the distance between the electrodes $\mathrm{M}$ and $\mathrm{N}$ is 

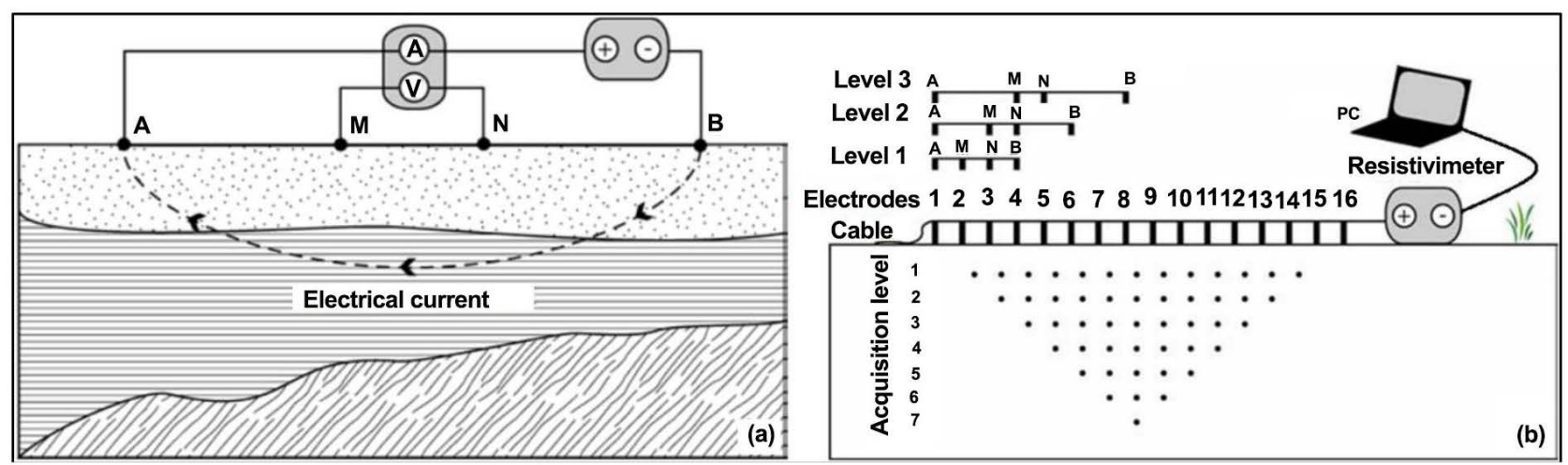

Figure 5. Principle of measurement of the apparent resistivity of the subsoil using a device Quadrupole in sounding (a) and electrical tomography (b).

significantly lower than that between the electrodes A and B, with the aim of minimizing the potentials derived from telluric and vagrant currents.

In electrical tomography (ERT), we employ a large number of electrodes (72 or 96) at fixed distance ( $10 \mathrm{~m}$ for example) connected to a multicore cable 710 to $950 \mathrm{~m}$ in length and placed in a pattern (Figure 5(b)). A laptop, in which the measurement sequence is programmed, is connected to a communication box and automatically selects the electrodes used for the current injection and the potential measurement according to the Wenner-Schlumberger device with the aim of having a better resolution of horizontal and vertical structures. The current is injected via a resistivity meter and the Switches allow executing a previously chosen measurement sequence.

While the electrical soundings allow to obtain the vertical succession of resistivities at the center of the device at different depths, the electrical tomography allows to obtain a continuous geoelectric imaging of the subsoil, i.e. a pseudo-section in resistivity as a function of the depth where the distribution of the resistivity varies vertically and horizontally along the profile [29] [30]. This electrical imagery would represent the combination of soundings and electric tows.

In the electrical tomography method, in which the multi-electrode cable and the number of electrodes are limited, it is necessary to perform the acquisition in "Roll-Along" mode [31] [32] [33]. Put differently, this performance aims to extend the tomography profiles by adjusting their length depending on the desired objective. This technique consists of covering a previous profile with a new profile (Figures 6-8). In this case, it was possible to apply the covers $2 / 3,5 / 8$ and $3 / 4$, where the depth of investigation obtained is significantly greater than the depth of the roofs of the Miocene marl to Upper Cretaceous. The covers used in the framework of this work are illustrated in Figures 6-8 below.

- Coverage $2 / 3 \mathrm{Max}$ is used to cover the $2 / 3$ of the maximum investigation depth of $132 \mathrm{~m}$ with 72 electrodes spaced $10 \mathrm{~m}$ apart, i.e. an investigation depth of $88 \mathrm{~m}$ with the Wenner-Schlumberger device (Figure 6);

- Coverage 5/8 Max is used to cover 5/8 of the maximum depth of $176 \mathrm{~m}$ with 96 electrodes spaced $10 \mathrm{~m}$ apart, i.e. a depth of investigation of $110 \mathrm{~m}$ with the Wenner-Schlumberger device (Figure 7); 


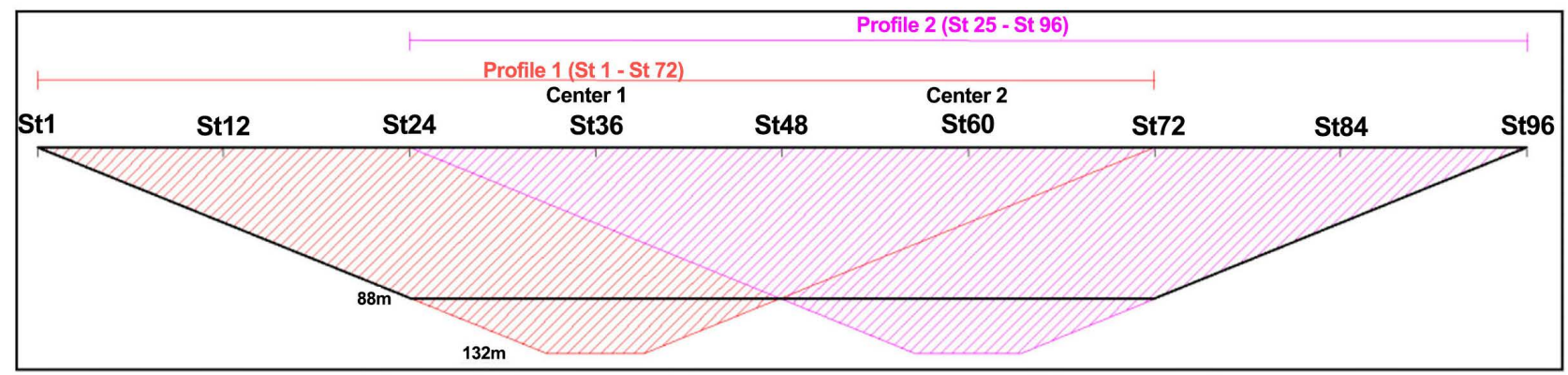

Figure 6. Principle of the Roll-Along method (2/3 coverage).

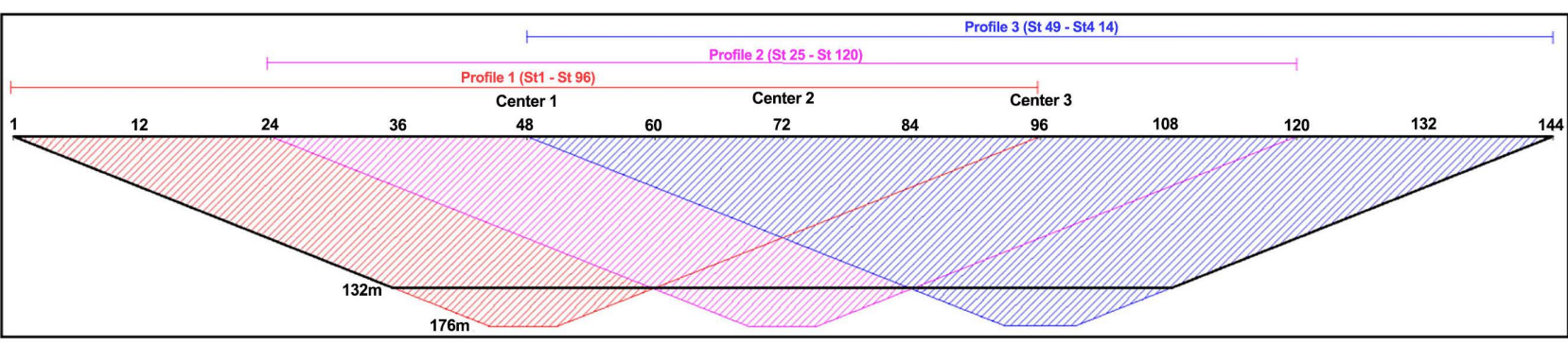

Figure 7. Principle of Roll-Along method (7/8 coverage).

- Coverage 3/4 Max is used to cover 3/4 of the maximum depth of $176 \mathrm{~m}$ with 96 electrodes spaced $10 \mathrm{~m}$ apart, i.e. an investigation depth of $132 \mathrm{~m}$ with the Wenner-Schlumberger device (Figure 8);

It is important to note that geoelectric methods (sounding and tomography) are affected by the principles of equivalence and delete principles.

In the electrical survey, all the measurements obtained for each chosen length will be plotted on charts to bilogarithmic scales. The GeoStudi's SEV along with the software will allow, after the smoothing of the curve and the data inversion, to obtain a mathematical model that gives, in turn, the depths of the roofs and walls of the different layers directly above the center of the electrical sounding. This model will be readjusted by the geophysicist in order to have a better estimate of the true resistivity for each layer while remaining within the equivalence limits.

In electrical tomography, after the transfer of apparent resistivity measurements acquired, the results obtained will be represented along a pseudo-section in apparent resistivity as a function of the depth. Data inversion using Res2dinv software will provide a mathematical model of true resistivity [34].

The lithological sections with the logs were used for calibration and geological identification of the geoelectric layers put by the diagrams of the electrical soundings.

In order to confirm the results of the interpretation of the electrical soundings, it was possible to carry out five (05) electrical tomography profiles (Figure 9) with a total length of $7870 \mathrm{~m}$ to the right of the significant recovery zones. The marly substratum roof is located on the right and left banks of Oued Saguia El Hamra and on the right of the depressions of the left bank of Oued Saguia El 


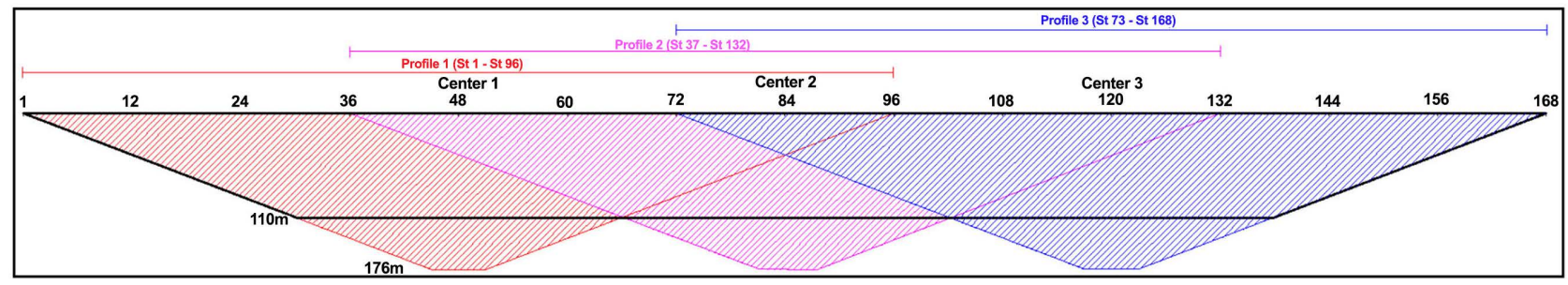

Figure 8. Principle of the Roll-Along method (3/4 coverage).

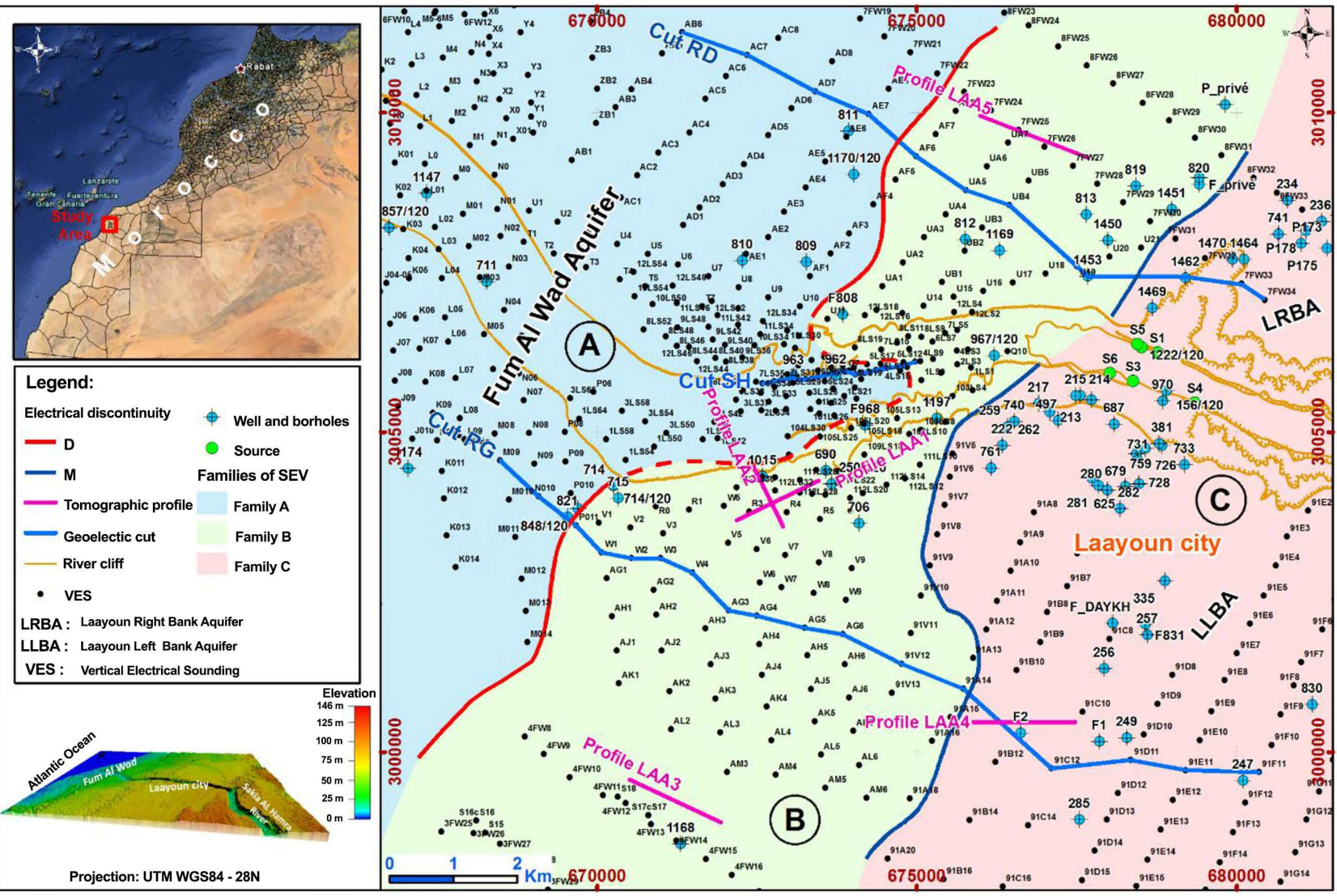

Figure 9. Location map of the study area, the MNT, electrical soundings, tomography and geoelectrical sections.

Hamra. These profiles are executed with the so-called "Roll Along" technique with the Max covers of 2/3,5/8 and 3/4 (Table 1). These tomography profiles were performed with the Wenner-Schlumberger device with 72 and 96 electrodes spaced $10 \mathrm{~m}$ apart to access depths of 132 and $176 \mathrm{~m}$, respectively.

1) Roll along Cover of the 2/3 (4/6): Pseudo-section of electrical tomography of 06 bobines of the $120 \mathrm{~m}$ each with a length of $710 \mathrm{~m}$ (72 electrodes). This pseudo section is extended using the roll-allong of two bobines with a length of $240 \mathrm{~m}$. This is in order to obtain the continuous geoelectrical imaging of the under-ground with an investigation depth of $90 \mathrm{~m}$, along a profile of $1430 \mathrm{~m}$ (Named LAA1 profile) and $1190 \mathrm{~m}$ (Named LAA2).

2) Roll along Cover of the 5/8: Pseudo-section of electrical tomography of 08 bobines of the $120 \mathrm{~m}$ each with a length of $950 \mathrm{~m}$ (96 electrodes). Extended each 
Table 1. Realized electrical tomography work.

\begin{tabular}{|c|c|c|c|c|c|c|c|c|}
\hline Profile & $\begin{array}{c}\text { Profile } \\
\text { Length (m) }\end{array}$ & $\begin{array}{l}\text { Number } \\
\text { electrode }\end{array}$ & $\begin{array}{c}\text { Blanket } \\
\text { (Roll along) }\end{array}$ & $\begin{array}{c}\text { Investigation } \\
\text { Depth (m) }\end{array}$ & $\begin{array}{l}\text { Single } \\
\text { tomography }\end{array}$ & Stations & $\begin{array}{c}\text { Single } \\
\text { Tomography } \\
\text { Length }(\mathrm{m})\end{array}$ & $\begin{array}{c}\text { Investigation } \\
\text { Depth (m) }\end{array}$ \\
\hline \multirow{4}{*}{ LAA1 } & \multirow{4}{*}{1430} & \multirow{4}{*}{144} & \multirow{4}{*}{ 2/3 $\operatorname{Max}^{(1)}$} & \multirow{4}{*}{90} & LAA11 & $1-72$ & 710 & 132 \\
\hline & & & & & LAA12 & $25-96$ & 710 & 132 \\
\hline & & & & & LAA13 & $49-120$ & 710 & 132 \\
\hline & & & & & LAA14 & $73-144$ & 710 & 132 \\
\hline \multirow{3}{*}{ LAA2 } & \multirow{3}{*}{1190} & \multirow{3}{*}{120} & \multirow{3}{*}{$2 / 3 \operatorname{Max}^{(1)}$} & \multirow{3}{*}{90} & LAA21 & $1-72$ & 710 & 132 \\
\hline & & & & & LAA22 & $25-96$ & 710 & 132 \\
\hline & & & & & LAA23 & $49-120$ & 710 & 132 \\
\hline \multirow{3}{*}{ LAA3 } & \multirow{3}{*}{1670} & \multirow{3}{*}{168} & \multirow{3}{*}{$5 / 8 \operatorname{Max}^{(2)}$} & \multirow{3}{*}{110} & LAA31 & $1-96$ & 950 & 176 \\
\hline & & & & & LAA32 & $37-132$ & 950 & 176 \\
\hline & & & & & LAA33 & $73-168$ & 950 & 176 \\
\hline \multirow{3}{*}{ LAA4 } & \multirow{3}{*}{1670} & \multirow{3}{*}{168} & \multirow{3}{*}{$5 / 8 \operatorname{Max}^{(2)}$} & \multirow{3}{*}{110} & LAA41 & $1-96$ & 950 & 176 \\
\hline & & & & & LAA42 & $37-132$ & 950 & 176 \\
\hline & & & & & LAA43 & $73-168$ & 950 & 176 \\
\hline \multirow{4}{*}{ LAA5 } & \multirow{4}{*}{1670} & \multirow{4}{*}{168} & \multirow{4}{*}{ 3/4 $\operatorname{Max}^{(3)}$} & \multirow{4}{*}{132} & LAA51 & $1-96$ & 950 & 176 \\
\hline & & & & & LAA52 & $25-120$ & 950 & 176 \\
\hline & & & & & LAA53 & $49-144$ & 950 & 176 \\
\hline & & & & & LAA54 & $773-168$ & 950 & 176 \\
\hline
\end{tabular}

time by 03 bobines of the $360 \mathrm{~m}$. This is in order to obtain the continuous geoelectrical imaging of the under-ground with an investigation depth of $110 \mathrm{~m}$, along a profile of $1670 \mathrm{~m}$ (Named LAA3 and LAA4 profiles).

3) Roll along Cover of the 3/4 (6/8): Pseudo-section of electrical tomography of 08 bobines of the $120 \mathrm{~m}$ each with a length of $950 \mathrm{~m}$ (96 electrodes). Extended each time by 02 bobines of the $240 \mathrm{~m}$. This is in order to obtain the continuous geoelectrical imaging of the under-ground with an investigation depth of $132 \mathrm{~m}$, along a profile of $1670 \mathrm{~m}$ (Named LAA5 profile).

Figures 6-8 and Table 1 illustrate the different roll-along covers used for this work.

The GF-Instruments ARES II multi-channel resistivity meters and licensed software for data transfer and processing (GEOSTUDI 2D mathematical inversion, Res2dinv, $\left.\mathrm{SEV}^{\text {plus }}\right)$ were used for the acquisition of new electrical soundings and electrical tomography profiles; this hardware and software is owned by AFRICA GEO-SERVICES.

The situation of the electrical soundings, the profiles of electrical tomography, the interesting water points of the study area (wells and boreholes) and the geoelectric sections are represented by Figure 9 .

\section{Results and Interpretation}

The interpretation of the electrical soundings and the correlation between them 
revealed the presence of three families of electrical soundings A, B and C, and each is characterized by a well-defined geoelectric response (Figure 9).

The electrical soundings families A and B are separated by the main electrical discontinuity $\mathrm{D}$, while $\mathrm{B}$ and $\mathrm{C}$ are separated by the electrical discontinuity $\mathrm{M}$. The diagrams of these electrical soundings (Figure 10) are representative of these electrical sounding families.

\subsection{Correlation of Electrical Soundings at the Level of Discontinuities D and M}

The electrical discontinuity $\mathrm{D}$ deduced from the correlation between the electrical soundings corresponds to a change in the geoelectric behavior of the conducting substratum $\mathrm{Cm}$ and the lower part of its cover (Figure 10). As a result, the set $(\mathrm{d} 1, \mathrm{Cm})$ is highlighted by the electrical sounding diagrams M09 (left bank) and AE7 (right bank) and the set (D1, Cs) is highlighted by the electrical soundings $\mathrm{W} 1$ of the left bank and AF6 of the right bank. Knowing that, according to the sections of the boreholes, the conducting substratum $\mathrm{Cm}$, located west of the discontinuity $\mathrm{D}$, is attributed to the gray marls of the Miocene representing the impermeable floor of the Foum El Oued aquifer. The Cs, located east of the electrical discontinuity $\mathrm{D}$, is attributed to gray-to-black marl of the Upper Cretaceous representing the impermeable floor of Laayoune aquifers. In this case, the intermediate level D1 surmounting the conducting substratum Cs, when it exists, would correspond to Miocene marl formations rich in past sand and/or sandstone. This subsequently allowed to increase its resistivity value reaching 10 and $14 \mathrm{ohm} \cdot \mathrm{m}$ respectively at right of electrical soundings $\mathrm{W} 1$ and AF6. This intermediate level D1 is absent at the level of Oued Saguia El Hamra.

At the level of the bed of Oued Saguia El Hamra, this electrical discontinuity seems to represent the contact between Miocene marly facies formations of marine origin in the west and facies wadi bedding formations and the Clay of continental origin of Quaternary age in the east. As a result, its layout remains hypothetical at the level of Oued Saguia El Hamra.

The correlation made between electrical soundings $8 \mathrm{FW} 31$ and $8 \mathrm{FW} 32$ on the right bank and $91 \mathrm{~A} 14$ and $91 \mathrm{C} 12$ on the left bank (Figure 11) revealed the presence of the electrical discontinuity $\mathrm{M}$ corresponding to a lateral change of facies at the level of the substrate marly driver. It is represented at the eastern limit of the extension of the Oligo-Miocene trench, while in the East of the electrical discontinuity $\mathrm{M}$, the intermediate level $\mathrm{D} 1$ (Miocene), highlighted by the diagrams of the electrical soundings 8FW31 (right bank) and 91A14 (left bank) did not show electrically to the east of this discontinuity and that the plio-quaternary formations, in namely the resistant level R2 admitted aquifer, deposited directly on the conducting substratum Cs attributed to age marl Upper Cretaceous. On the contrary, the west of the electrical discontinuity $\mathrm{M}$, where the electrical levels R2 and D1 are sterile, belongs to the rising zone of the roof of the Miocene marls at the Upper Cretaceous. 

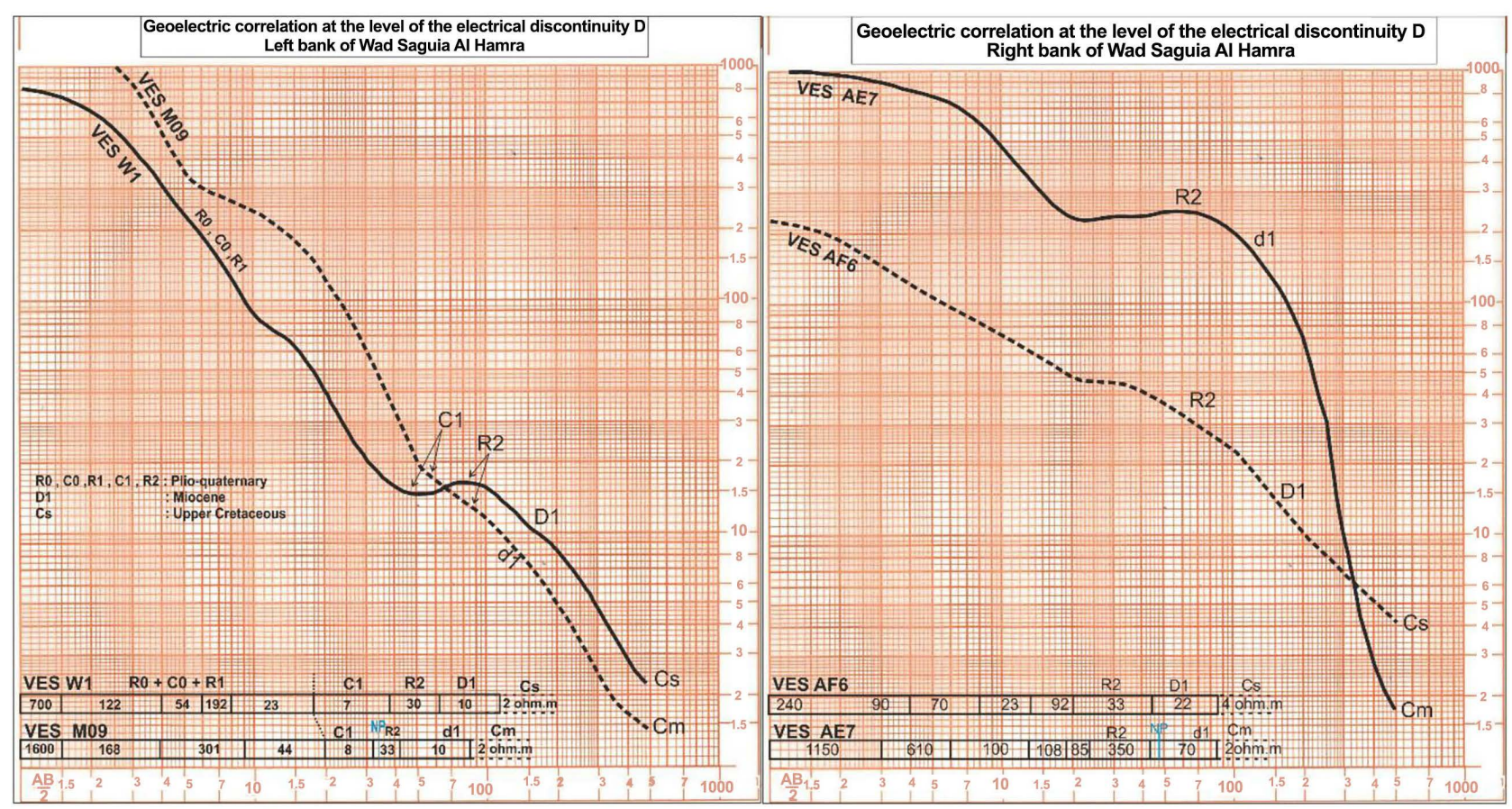

Figure 10. Geoelectric correlation at the electrical discontinuity D, left and right bank of Oued Saguia El Hamra.

The families of electrical soundings A, B and C are separated by the two (02) electrical discontinuities $\mathrm{D}$ and $\mathrm{M}$ with a substantially NE-SW orientation.

\subsection{Examination of Electrical Soundings}

The western zone of the $\mathrm{D}$ discontinuity, characterizing the eastern part of the Foum El Oued aquifer, is represented by the M09, AE7 (Figure 10) and 5LS23, 6LS30 (Figure 11) electrical soundings. These four electrical soundings belong to the family A.

The examination of these diagrams shows the presence of the roof substrate conductor $\mathrm{Cm}$ reaching a depth of $84 \mathrm{~m}$ in line with the electrical soundings M09 and AE7. This substratum, corresponding to the gray marl of the Miocene, is surmounted by a very heterogeneous set represented by an alternation of resistant and conductive layers of Plio-quaternary age.

From the surface, the examination of the 5LS23 borehole diagram at hole 962/120 (Figure 12) shows the presence of the following geoelectric levels:

- A superficial, very shallow, level of resistance attributed to dry dune sands;

- Two descending intermediate levels id1 and id2 with a thickness close to 20 $\mathrm{m}$ that correspond to the fine and coarse interbedded sands of marls and clays constituting the aquifer;

- An underlying conductive level $\mathrm{cl}(1.5 \mathrm{ohm} \cdot \mathrm{m}-19 \mathrm{~m})$ assimilated to marl and flinty clay;

- A less resistant level $\mathrm{r} 2(5 \mathrm{ohm} \cdot \mathrm{m}-20 \mathrm{~m})$ where its low resistivity value shows that it is the presence of past marl interspersed with past resistant permeable containing water loaded with salts; 

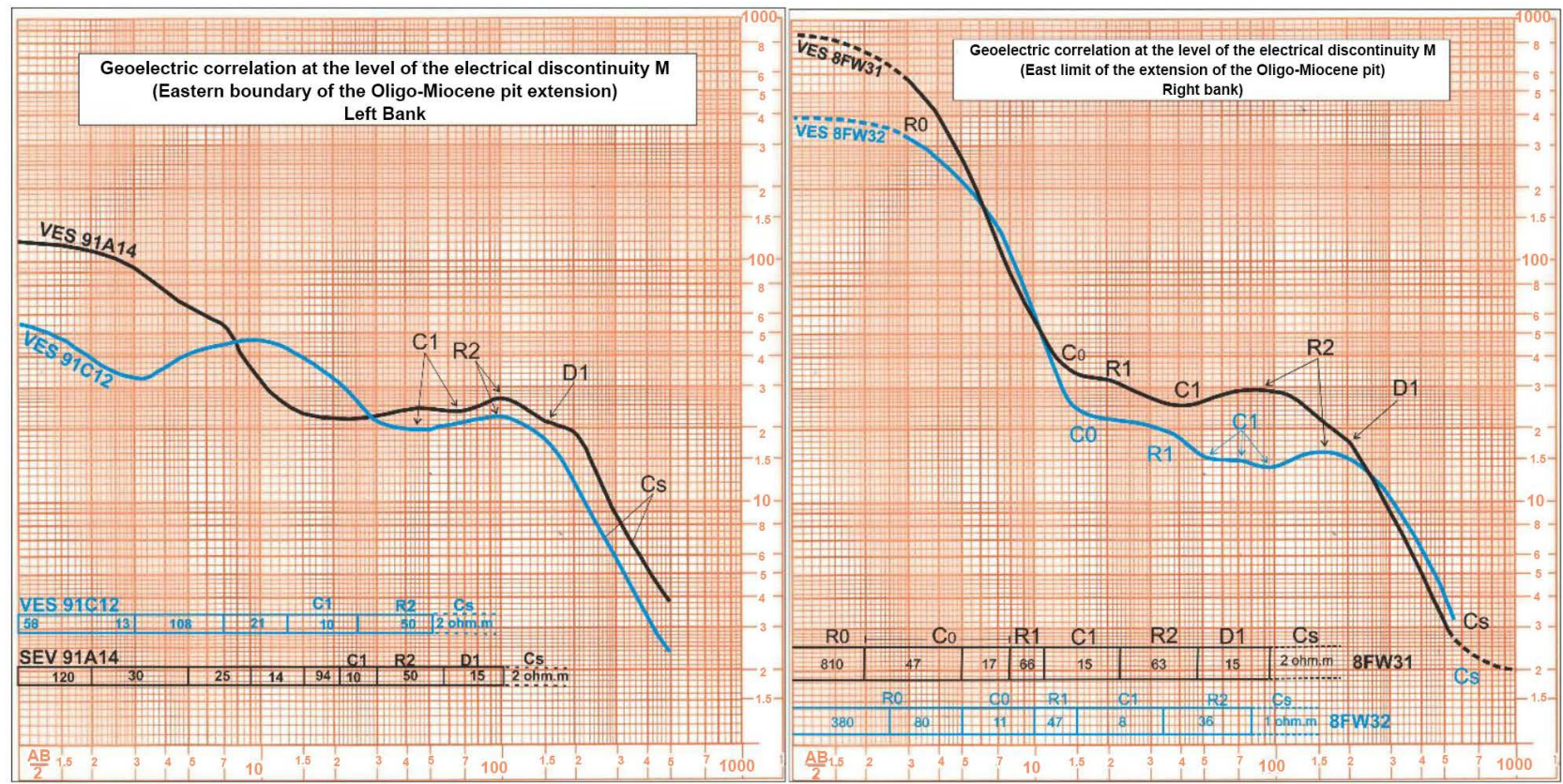

Figure 11. Geoelectric correlation at the electrical discontinuity M, (East limit of the electrical extension of the Oligo-Miocene pit). Left and right bank of Oued Saguia El Hamra.
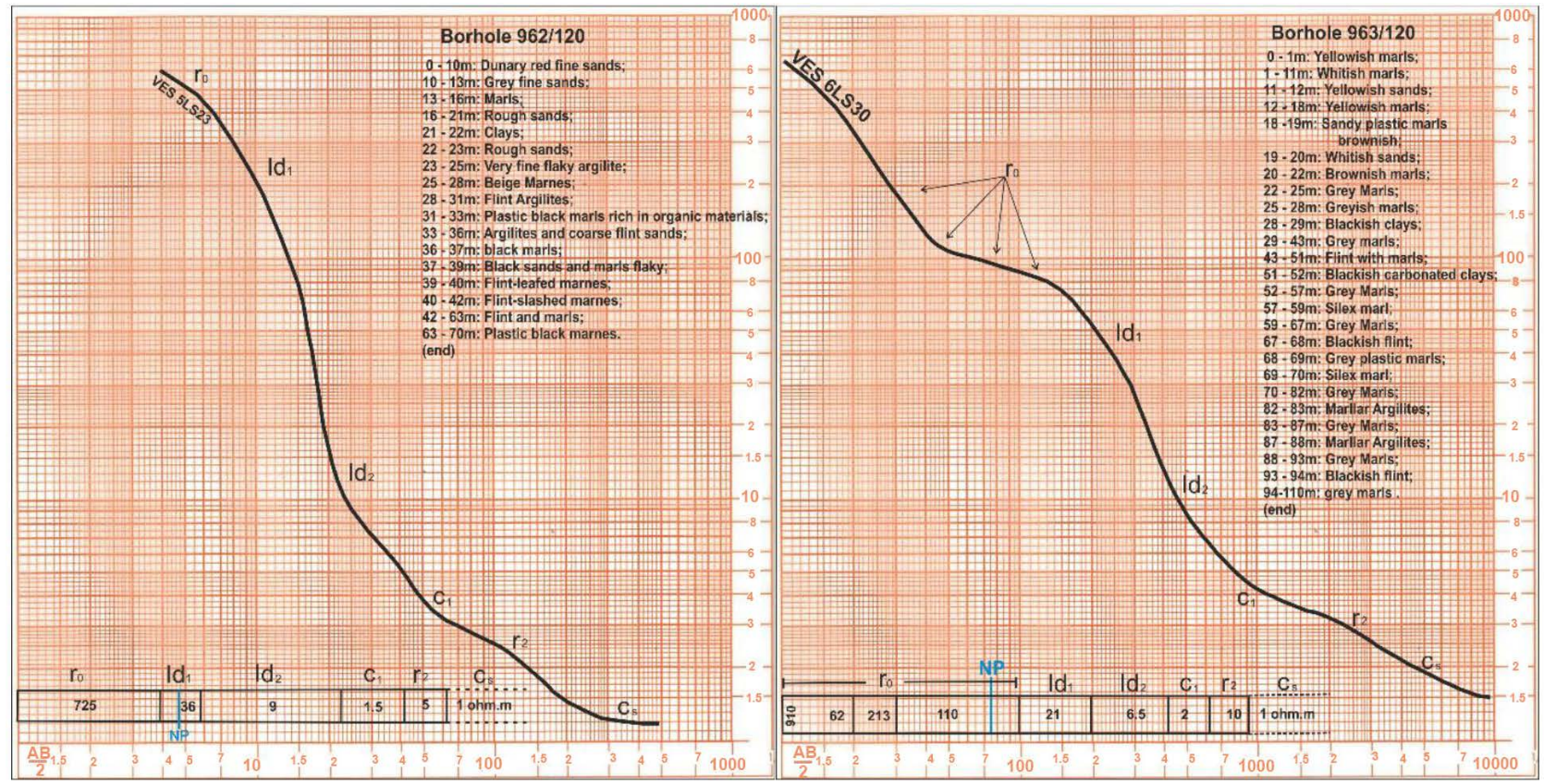

Figure 12. Diagram of parametric polls 5LS23 and 6LS30.

- Basically, a conductive substratum Cs is attributed to the gray plastic marls whose roof is located at $63 \mathrm{~m}$ depth.

On the standard drilling pattern 6LS30 at hole 963/120 (Figure 12), we find the same succession of resistant and conductive layers ( $\mathrm{r} 0, \mathrm{~d} 1, \mathrm{~d} 2, \mathrm{cl}, \mathrm{r} 2, \mathrm{Cs})$ highlighted by the previous diagram with yet a significant development of the cover of the conductive substrate Cs. The high salinity measured (>25 g/l in 
$\mathrm{NaCl}$ equivalent) is responsible for the decrease in the resistivity of the resistor level r2 (10 ohm $\cdot \mathrm{m})$ (Figure 13).

The area between the electrical discontinuities D and M (family B) is characterized by the presence of a rise in the roofs of marl levels of Miocene and Upper Cretaceous age at the left and right banks of Oued Saguia El Hamra. This rise is absent at the level of the wadi and its borders where the rooftops marly levels draw a monoclinale structure plunging regularly from Laayoune to Foum El Oued.

Electrical soundings 4FW14 and UB3 (Figure 14) are respectively characteristic of soundings belonging to the left and right banks. They are located in the vicinity of the 1168/120 drillings of the right bank and 1169/120 of the right bank which is dry. Their lithological section is used for the geological identification of the geoelectric levels highlighted by the diagrams of these electrical soundings.

The interpretation of the diagram of the SEV 4FW14 located on the left bank in the vicinity of the borehole 1168/120 shows, from the surface, a highly heterogeneous resistance assembly with a power of $50 \mathrm{~m}$ attributed to the plio-quaternary formations mainly sandstones and sandstones fine to medium sands. This set overcomes the intermediate level D1 (56 ohm.m) which corresponds to gray marl with Miocene sands. The whole rests on the infinitely marly substratum Cs of upper Cretaceous age. Its roof reaches a depth of $90 \mathrm{~m}$.

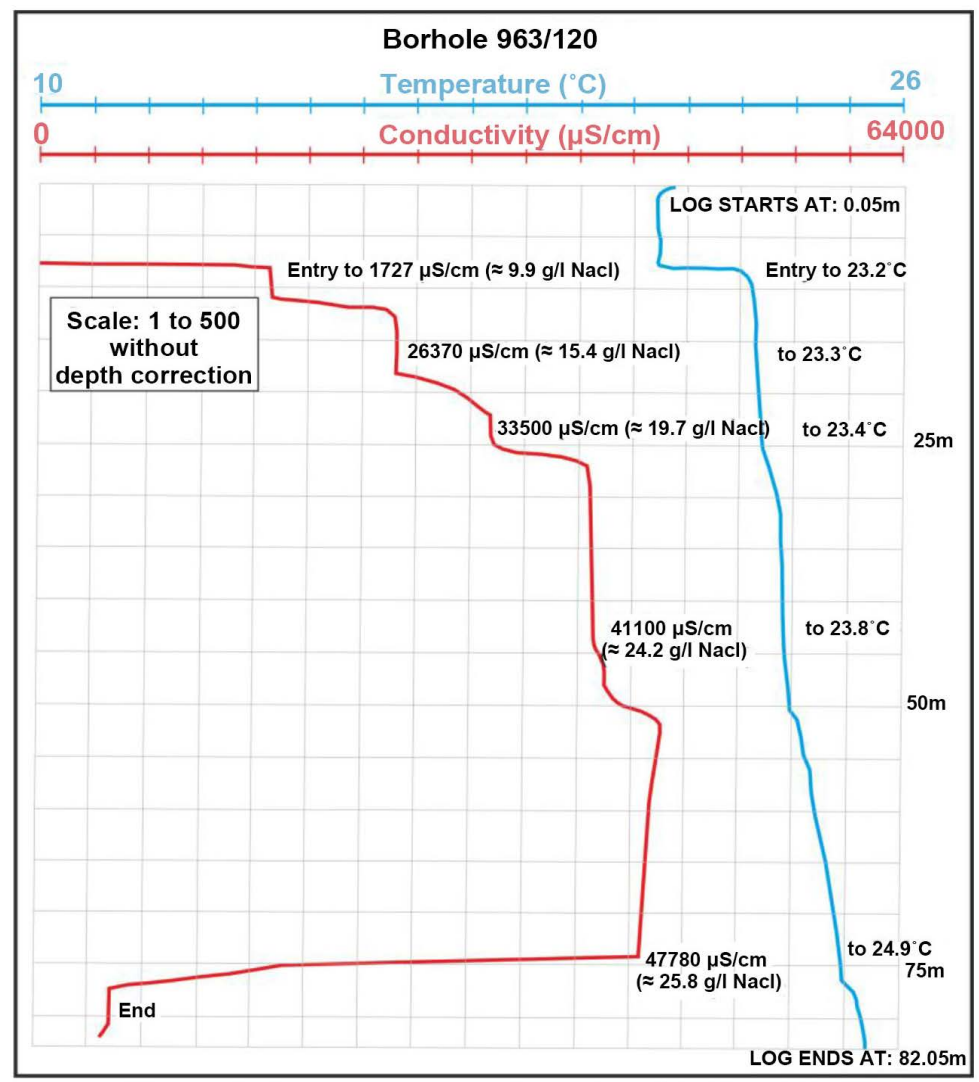

Figure 13. Recording of the salinometry of drilling 963/120 (Hydraulic Regional Direction of Sahara, 2003). 


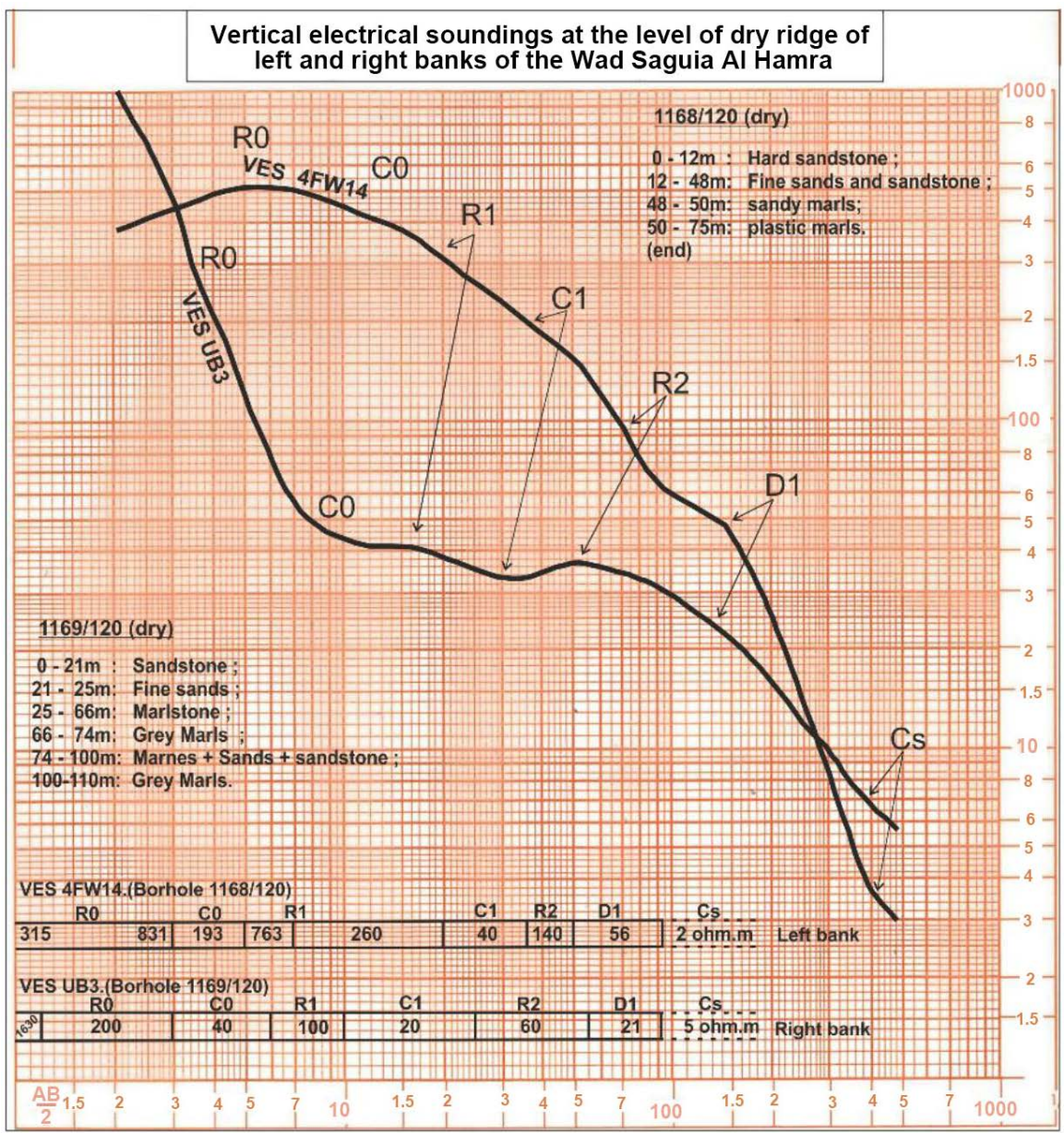

Figure 14. 4FW14 and UB3 electrical sounding diagrams.

On the right bank, in the vicinity of 1169/120 drilling, the SEV UB3 diagram has, in its lower part, the same geoelectric response as that of the preceding diagram. Indeed, we find the intermediate level D1 (21 ohm.m) resting on the Cs conductive substrate where their roof respectively reaches depths of 55 and 100 m.

The area east of the $\mathrm{M}$ discontinuity is marked by the absence of Miocene marls (D1 and Cm levels). The impermeable floor of Laayoune aquifer is represented by greyish to greenish marls of late Cretaceous age.

This zone is represented by the 256/120 standard drillings executed in line with the drilling 256/120 (left bank) and 8FW34 executed in the vicinity of the drilling 235/120 (right bank). The roof of the conductive substrate Cs is located at a depth of $50 \mathrm{~m}$ in both cases.

The interpretation of the standard drill pattern 256/120 (Figure 15) shows, from the surface, the presence of an alternation of resistant and conductive layers attributed to hard and soft sandstone with a thickness of $24 \mathrm{~m}$. Under this alternation, there is the presence of a resisting level R2 well-marked on the diagram and attributed to soft sandstone, sand and limestone lumachellic of a global resistivity of $46 \mathrm{ohm} \cdot \mathrm{m}$ and a thickness of $26 \mathrm{~m}$. 


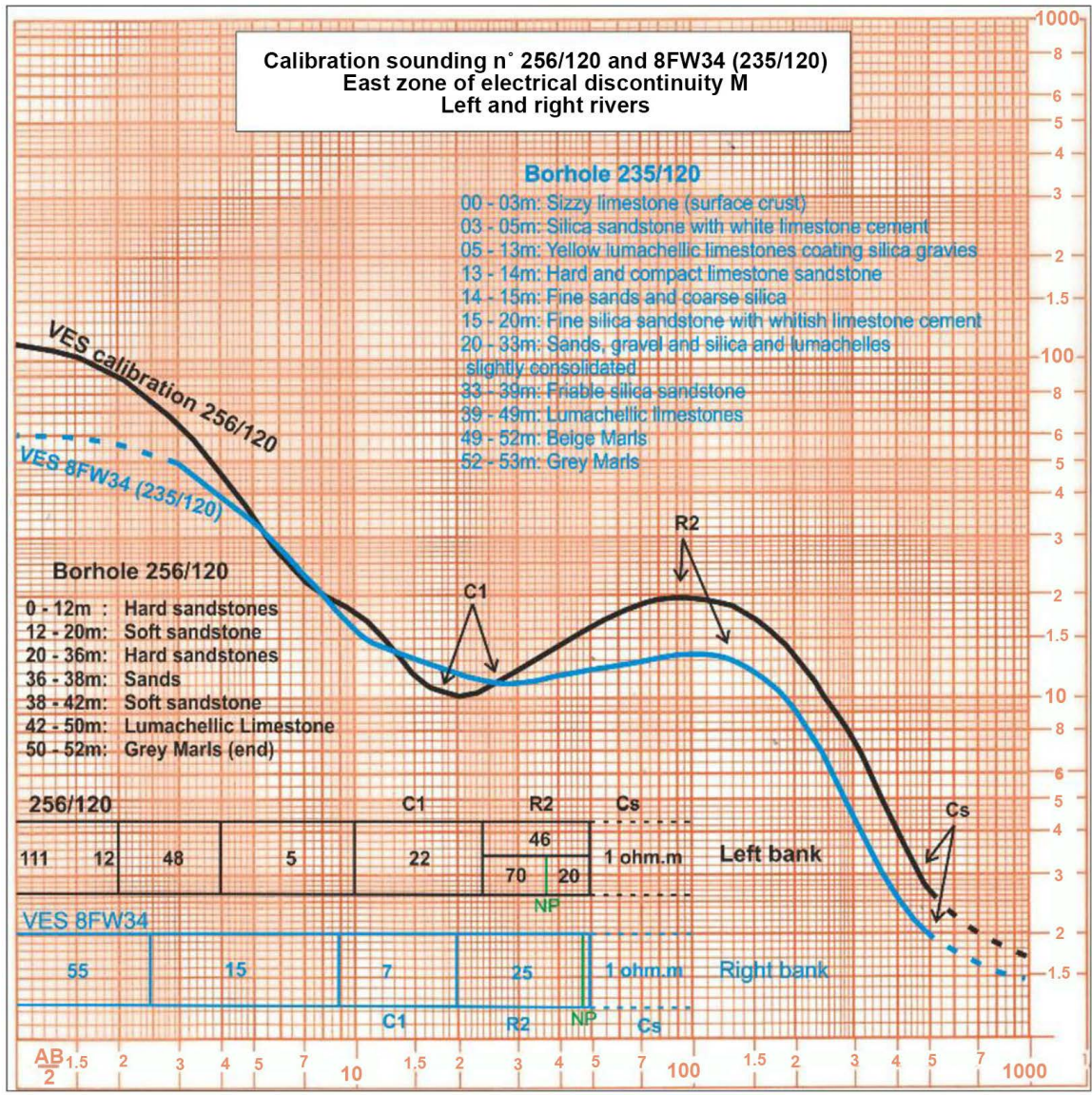

Figure 15. Diagrams of standard electrical soundings 256/120 and 8FW34.

On the right bank, the standard electrical sounding pattern 8FW34 (235/120) has the same geoelectric cutoff as that shown by the standard sounding pattern $256 / 120$. Indeed, we find the same succession of resistant and conductive layers constituting the covering of the conducting substratum Cs, namely the resistant R2 admitted aquifer.

\subsection{Examination of Electrical Tomography Profiles}

Following the results obtained from the quantitative interpretation of the electrical soundings the five electrical tomography profiles LAA1, LAA2, LAA3, LAA4 and LAA5 were made (Figure 9) to confirm these results especially at the level of the ridge (high zone) and the brackish water drainage zones of Laayoune aquifer towards the sources (low zones), located north and south of the town of Laayoune, east of the electrical discontinuity M,The contribution of this geophysical method by electrical tomography has been widely proven in several cases from geophysical survey to the structural mapping of aquifers that are superficial or semi-deep.

The first three profiles LAA1, LAA2 and LAA3 concern the ridge of the left bank (h1), while the LAA 5 addresses the dorsal of the right bank (h3). As for the profile LAA4, it concerns the low zone d1 (graben) belonging to the left bank. 
The ranges of true resistivity adopted and deduced from the interpretation of the electrical soundings close to the tomography profiles and were used for the data processing as follows:

- Conductive range where the resistivity is less than or equal to $20 \mathrm{ohm} \cdot \mathrm{m}(\mathrm{C} 0$, C1, Cs levels);

- Intermediate range where the resistivity is between 30 and $70 \mathrm{ohm} \cdot \mathrm{m}$ (intermediate level D1, resistant surface level R0 in the case where it is sandy facies and the resistant level R2 in the case where it is altered and fractured);

- Resistant range where the resistivity is well above $100 \mathrm{ohm} \cdot \mathrm{m}$ and reaches values above $500 \mathrm{ohm} \cdot \mathrm{m}$ in case the sandstone is compact and hard (resistant levels $\mathrm{R} 0$ and $\mathrm{R} 2$ ).

The results obtained are presented as a true resistivity model after the $2 \mathrm{D}$ mathematical inversion with the Res2DInv software developed by Loke and Barker (1996). On these true resistivity models, the geoelectric levels have been reported with their geological identifications, the limits of some electrical horizons and the observed electrical discontinuities.

Overall, at the dorsal level, between the electrical discontinuities $\mathrm{D}$ and $\mathrm{M}$, the analysis of the LAA1, LAA2, LAA3 and LAA5 electrical tomography profiles (Figure 16) reveals the presence of a plio-quaternary overlap (R0, C0, R1, C1 and R2) very heterogeneous (Moghrebian coastal platform) and affected by many electrical discontinuities, particulary the resistant level R2. The latter corresponds to the sandstone-lumachellic deposits of the Plio-Quaternary base, where its roof is located at depths ranging from 20 to $30 \mathrm{~m}$ and its wall at depths ranging from 40 to $50 \mathrm{~m}$ (LAA3 and LAA5 profile). These electrical discontinuities corresponded to lateral facies changes the faults that are synsedimentary and substantially NE-SW in direction. These natural faults structured the post-Miocene sandstone-lumachellic deposits and its essentially sandy cover into a horsts and grabens system.

The latter and the crumbling areas of the faults served as preferential drainage corridors of the groundwater. This drainage of the waters in the calcareous sandstone-lumachellic soils is faulted and crushed; it also favored their karstification which strongly contributed to a notable decrease in the resistivity especially of the resistant level R2. Indeed, this resistivity has passed values greater than $200 \mathrm{ohm} \cdot \mathrm{m}$ (healthy lumachellic sandstone) at values close to 50 to 70 $\mathrm{ohm} \cdot \mathrm{m}$, in the case where these lumachellic sandstones are altered by tectonic grinding and karstification.

These lumachellic sandstones (resistant level R2) are based on the ensemble (D1, Cs) attributed to Miocene to Late Cretaceous formations. These conductive, marly-dominant formations are well represented on the true resistivity models of the subsoil obtained along the electrical tomography profiles.

From the surface, on the model of resistivity LAA3 (left bank), one distinguishes the presence of the very resistant surface level R0 which represents the compact and hard sandstone of a resistivity definitely higher than $200 \mathrm{ohm} \cdot \mathrm{m}$ and a thickness average close to $20 \mathrm{~m}$. 


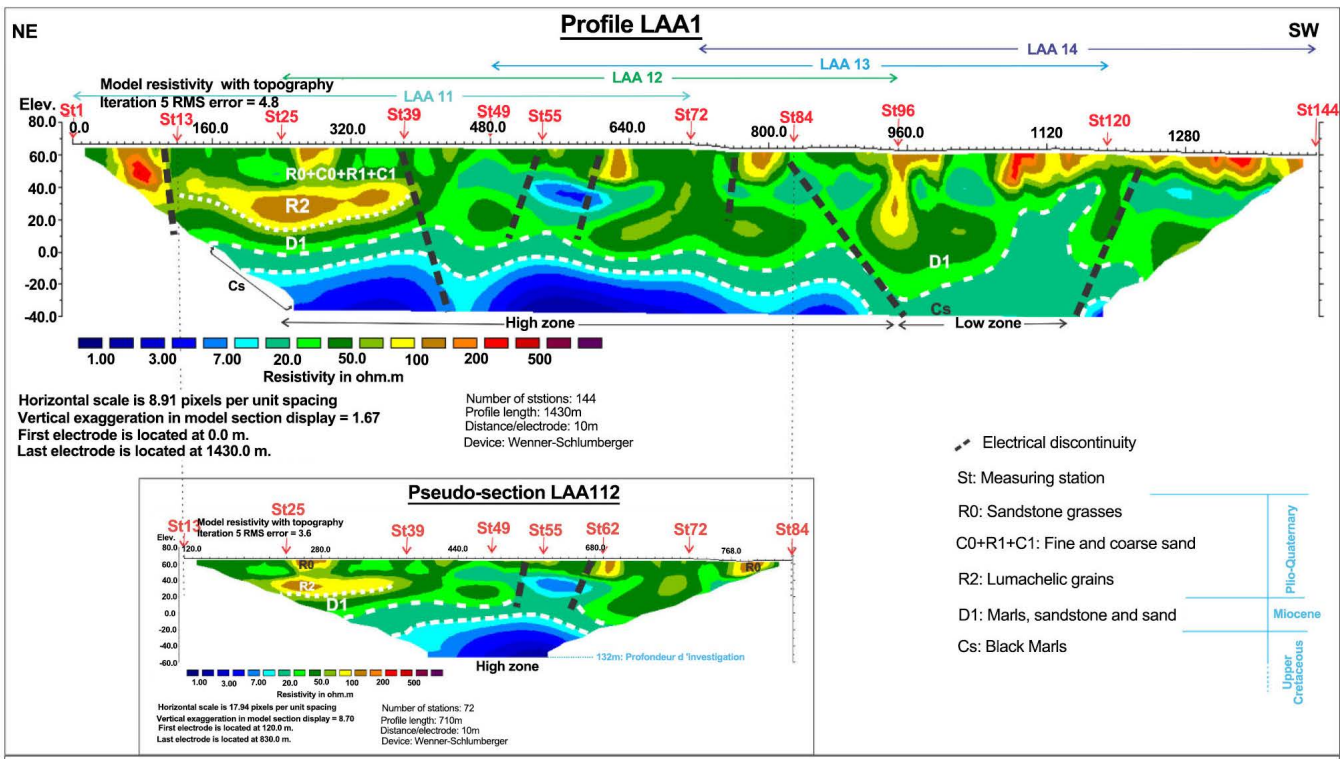

(a)

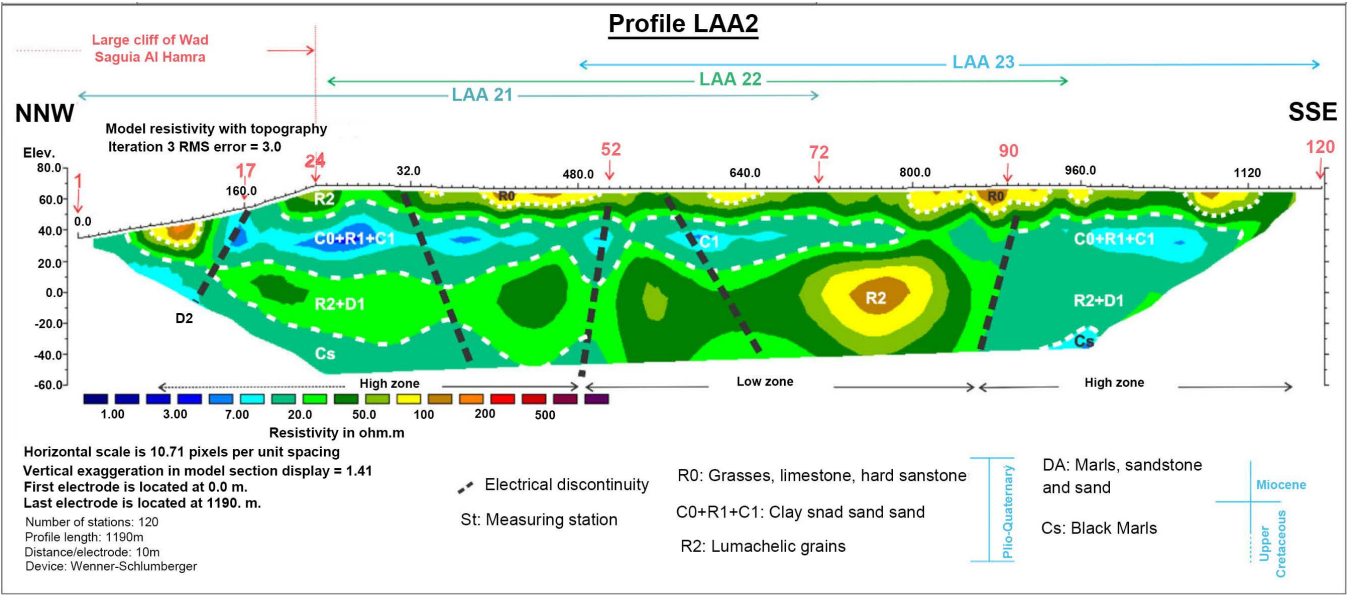

(b)

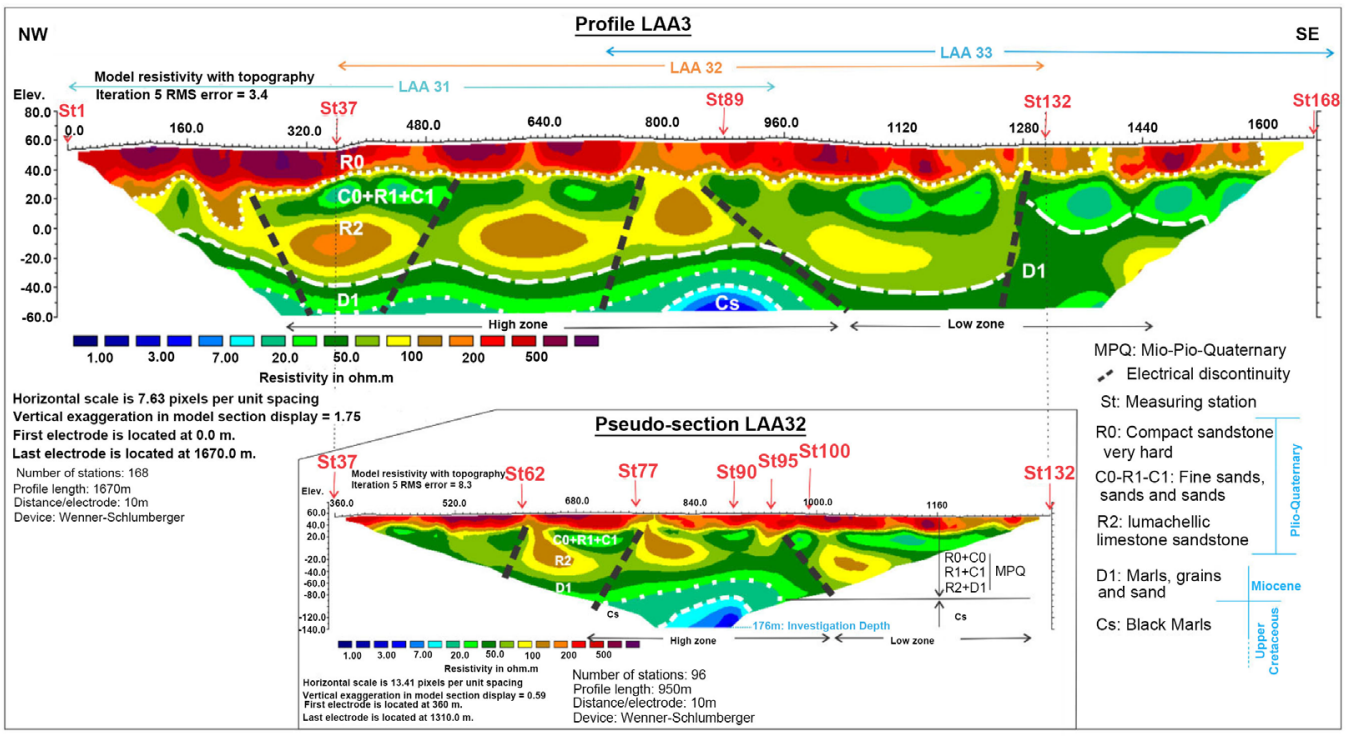

(c) 


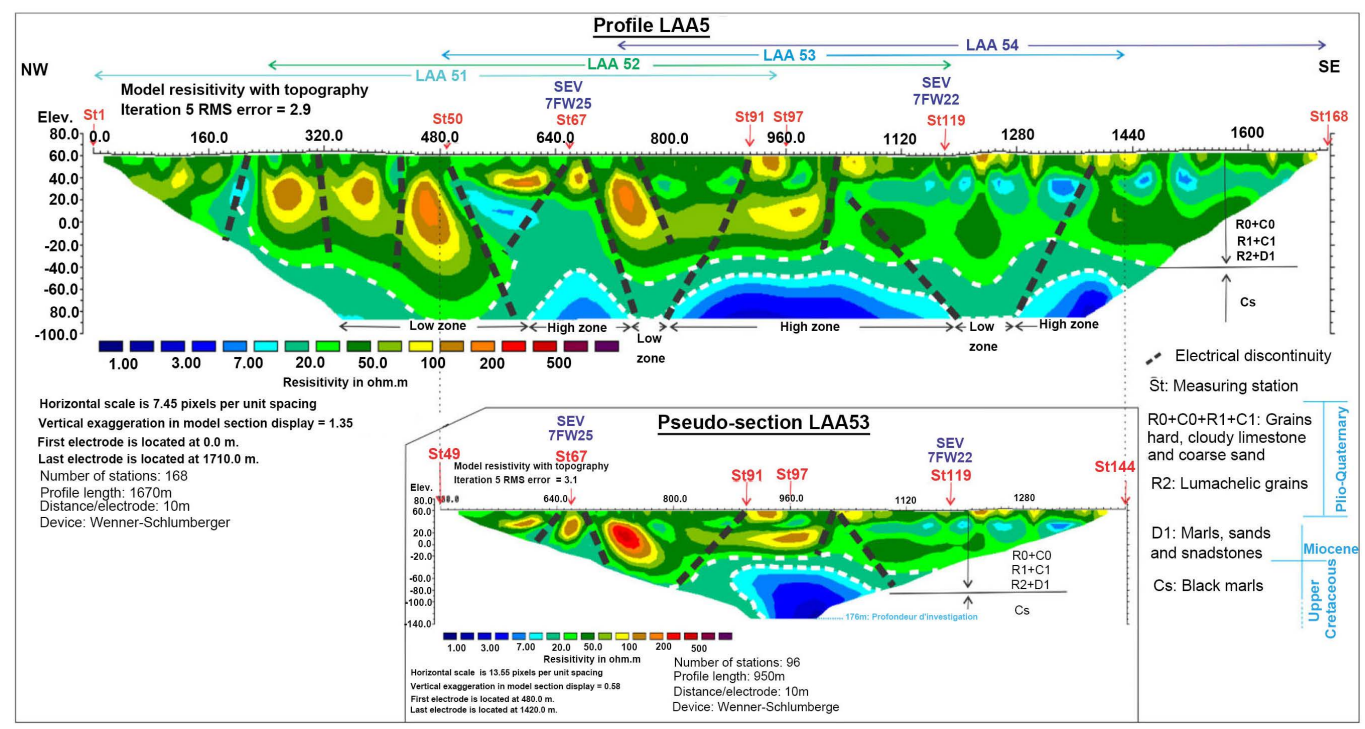

(d)

Figure 16. LAA1, LAA2, LAA3 and LAA5 electrical tomography profiles at the level of the ridge.

The underlying deposit (represented by fine sands, soft sandstone and clayey sand) which is none other than the set (C0, R1, C1), is electrically manifested as a conductive deposit in the case where this deposit is at marly facies (10 to 20 $\mathrm{ohm} \cdot \mathrm{m}$ ) and intermediate in the case where it is sandy facies (50 to $70 \mathrm{ohm} \cdot \mathrm{m}$ ). This deposit is based on the resistant level R2 corresponding to fractured and karstified lumachellic sandstones.

On the edge of the cliff of Oued Saguia El Hamra, and at the NNW of the LAA2 tomography profile, the electrical discontinuity D2, marked by a conductive zone, represents an erosion surface corresponding to an alluvial incision surface of Oued Saguia El Hamra in the marine formations of the Moghrebian slab (Plio-Quaternary). This incision surface also corresponds to a fault line.

East of the electrical discontinuity $M$, the examination of the pseudo-section in true resistivity obtained along the LAA4 profile that was carried out on the graben d1 (geoelectric section RG, Figure 17) shows the presence of plio-Quaternary cover (coastal marine deposits) as very heterogeneous and are affected by many electrical discontinuities that correspond to synsedimentary faults. The latter compartmentalized the conducting substratum Cs (black marl of the Upper Cretaceous) and its plio-quaternary cover into a system of horst and grabens. In particular, we will consider graben d1, located between stations 52 and 102, as the preferred groundwater drainage zone of Laayoune aquifer supplying the springs that drip at the cliff on the left bank of Oued Saguia El Hamra. Having been carried out near station 73 just after the acquisition of the LAA4 tomography data, Drilling F2 showed the presence of brackish water $(6.3 \mathrm{~g} / \mathrm{l})$ in the sandstone levels of the base of the plio-quaternary formations. The F1, located $1200 \mathrm{~m}$ east of the F2 borehole, is dry and appears to be located in a high zone (Horst). 


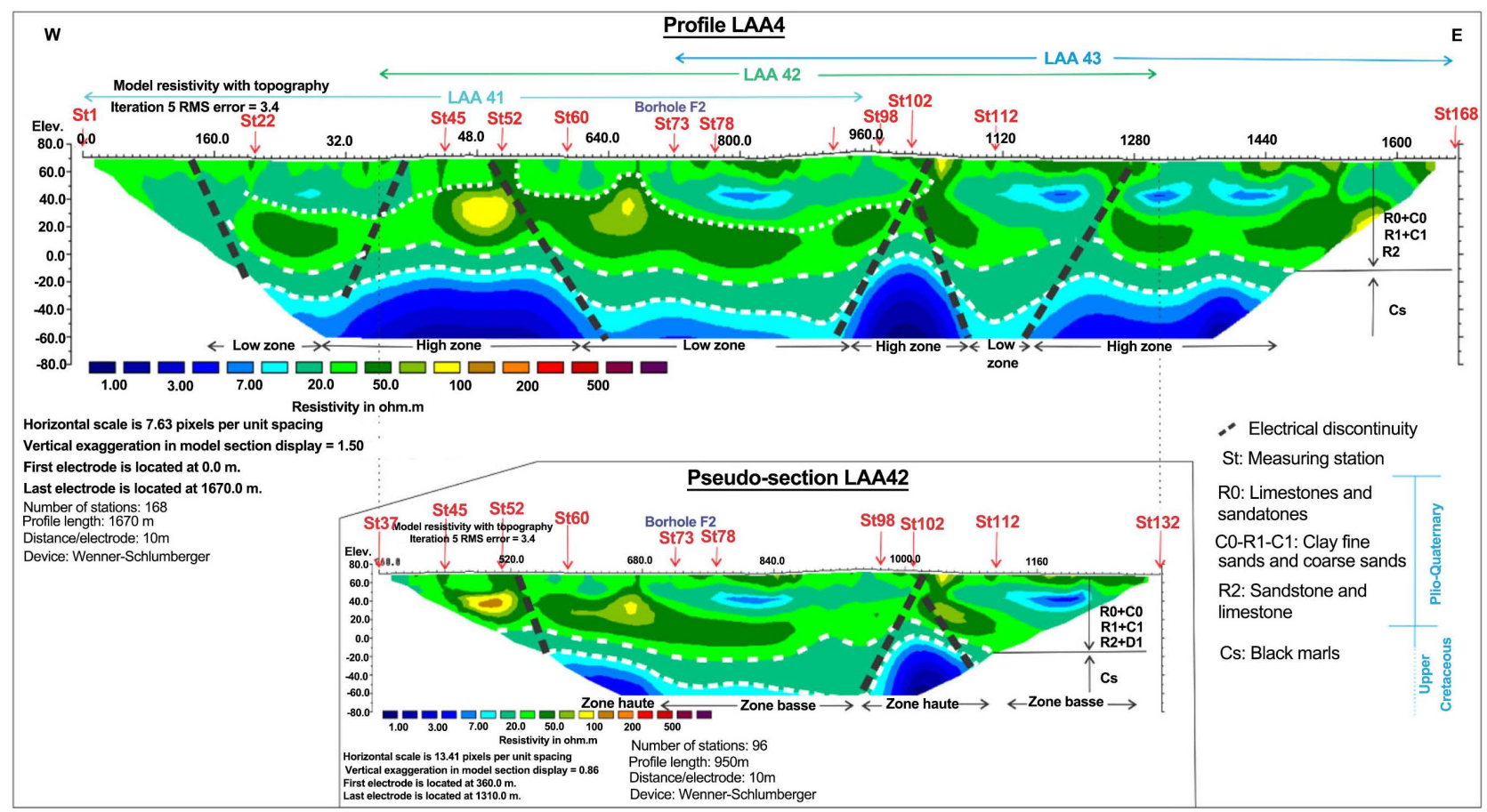

Figure 17. LAA4 electrical tomography profile (East of the M Electrical Discontinuity).

\subsection{Analysis of Geoelectric Sections}

Three geoelectric sections have been established (Figures 18-20) from the interpretation of the electrical soundings. The sections RD and RG concern the right and left bank, while the SH concerns the bed of Oued Saguia El Hamra. These sections, NW-SE orientation, are represented at the same horizontal scale $1 / 20,000$ and vertical scale of $1 / 2000$ to better individualize the different levels of plio-quaternary coverage.

The correlations made, in most cases, have a physical meaning based on the values of the true resistivity obtained at the right of each electrical survey after the treatment. These sections were used to prepare the map of the isohypses of the wall of the plio-quaternary formations (roof of the drivers $\mathrm{Cm}, \mathrm{cl}, \mathrm{D} 1$ and Cs).

Overall, the analysis of these sections shows a very heterogeneous plio-quaternary cover. They highlight the presence of two electrical discontinuities denoted D and $\mathrm{M}$ which affect the marnogenic conductive substratum and its plio-quaternary cover.

West of the electrical discontinuity $\mathrm{D}$, the analysis of RD and RG geoelectric sections shows the appearance of the conductive roof $\mathrm{Cm}$ attributed to the $\mathrm{Mi}$ ocene gray marl representing the impervious floor of the Foum El Oued aquifer. Its roof dips progressively from east to west. This conductive substratum is surmounted by very heterogeneous formations that enclose the Foum El Oued aquifer. The base of the plio-quaternary formations is represented by the resistant level R2 aquifer in its basal part represented by the intermediate level $\mathrm{d} 1$.

Along this section, there is the presence of numerous electrical discontinuities 


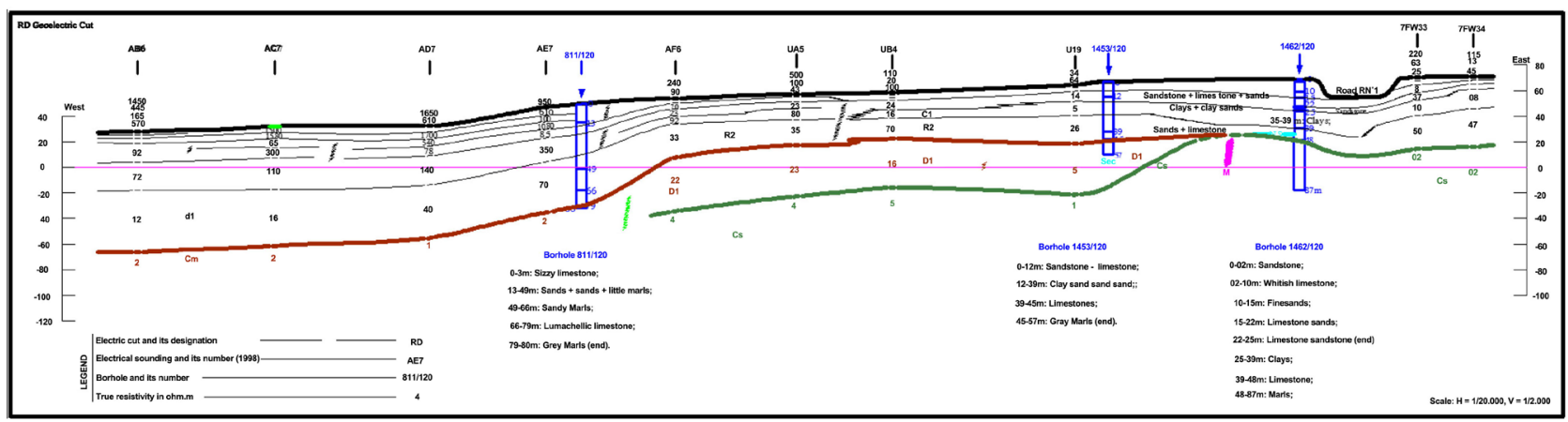

Figure 18. RD Geoelectrical cross-sections (right bank of the river Saguia el-Hamra).

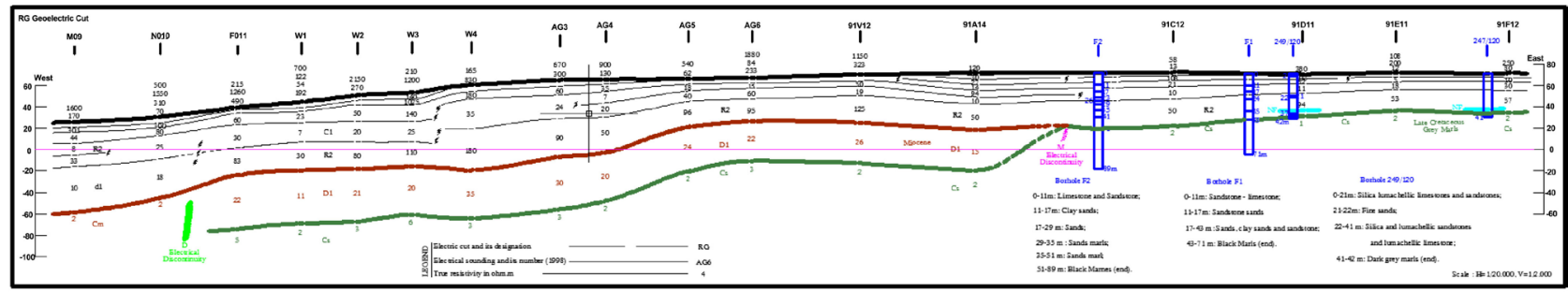

Figure 19. RG Geoelctrical cross-section (left Bank of Oued Saguia El Hamra).

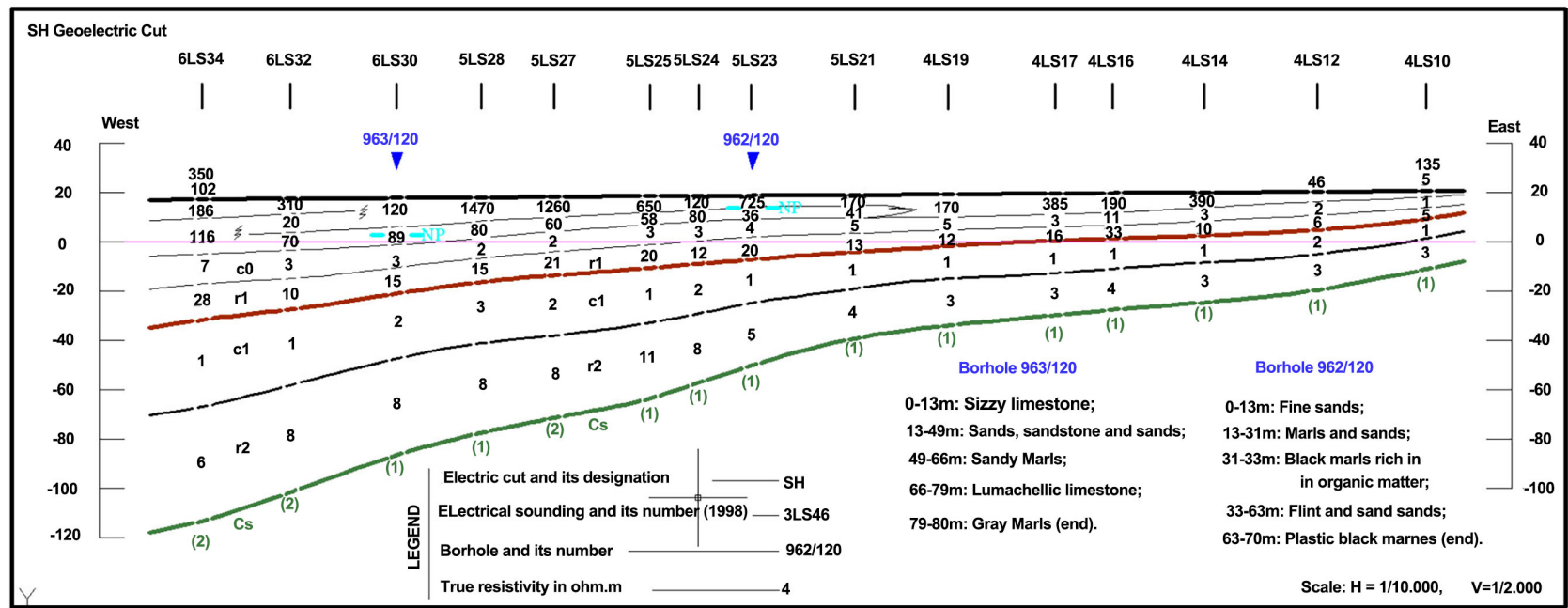

Figure 20. Geoelectrical cross-section SH (bed of Oued Saguia El Hamra).

affecting the coverage of the conductive level $\mathrm{Cm}$ that corresponds to erosion surfaces.

Between the electrical discontinuities $\mathrm{D}$ and $\mathrm{M}$, the presence of the resistant past (sand and sandstone) within the Miocene deposit and its eastward thinning contributed to the setting up of the Cs conductive substratum attributed to the blackish marls at greenish late Cretaceous age. In this case, the conductor $\mathrm{Cm}$ is electrically other than the intermediate level D1 representing the assembly consisting of sands, sandstones and marl sandy loams. At this level, there is a rise in the structure drawn particularly by the roof of the whole (D1, Cs).

East of the discontinuity $\mathrm{M}$, the overlap levels of the conducting substratum 
Cs, and in particular the resistance level R2 (lumachellic limestones), directly surmount the infinitely conducting substratum Cs. This substratum represents the impervious floor of the Laayoune aquifer in this zone. At the level of the right and left banks, this zone is marked by the presence of low zones drawn especially by the roof of the conducting substratum Cs.

The geoelectrical cross-section SH, oriented ESE-ONO (Figure 19), is established along Oued Saguia El Hamra downstream of the spreading zones through boreholes 962/120 and 963/120. It highlights the presence of the geoelectric levels shown on the diagrams of the 5LS23 (962/120) and 6LS30 (963/120) soundings.

This monoclinal structure, designed especially by the roofs of conducting levels $\mathrm{cl}$ and Cs plunging towards the ONO in the direction of Foum El Oued, has facilitated the flow of wastewater and brackish water from sources from the spreading zone to the 962 boreholes/120 and 963/120. Indeed, the chemical analyses carried out by the Direction of the Saharan Hydraulic Region (DRH) revealed the presence of a strong mineralization of about $20 \mathrm{~g} / \mathrm{l}$ at the $962 / 120$ drilling and $32 \mathrm{~g} / \mathrm{l}$ at the $963 / 120$ drilling explained by the presence of groundwater pollution as well as the wastewater over-salted by evaporation (HRD 2007). As for bacteriological analyzes, they revealed the presence of a high load of organic matter (12.5 mg/l at 962/120 and $123.9 \mathrm{mg} / \mathrm{l}$ at 963/120) and especially the presence of fecal coliforms at $10 \mathrm{CF} .100 \mathrm{ml}$ at $962 / 120$ drilling and total coliforms at $43 \mathrm{CT} / 100 \mathrm{ml}$ at $963 / 120$ drilling [35]. This confirms the presence of groundwater pollution in the sandy past represented by the intermediate level Id2 (Surveys 5LS23 and 6LS30). This pollution explains the low value of its true resistivity which hardly exceeds the $10 \mathrm{ohm} \cdot \mathrm{m}$.

\subsection{Examination of the Isohypse Map of the Wall of the Plio-Quaternary Formations}

The quantitative interpretation of the electrical soundings allows to draw the map of the isohypses of the wall of the plio-quaternary formations that represents the moghrebian slab (Coastal marine deposit) and gives an idea on the pace and the electrical behavior of the roofs of the conducting levels $\mathrm{Cm}, \mathrm{Cs}$, $\mathrm{cl}$ and intermediate D1 (Figure 21).

The correlation made between the different electrical soundings also allows to highlight the presence of two electrical discontinuities D and M. Indeed, the discontinuity represents the limit of the extension of the Miocene marl to the east except at the level of the bed of the Wadi or the course of this boundary which remains hypothetical from a geological point of view.

The isohypsum of the wall of the plio-quaternary formations varies considerably between values close to $-80 \mathrm{~m}$ west of the electrical discontinuity $\mathrm{D}$ and values greater than $20 \mathrm{~m}$ east of the electrical discontinuity $\mathrm{M}$.

West of Discontinuity D reflects the shape of the roof of the conductive substratum $\mathrm{Cm}$ attributed to the gray marls of the Miocene. It shows a general 


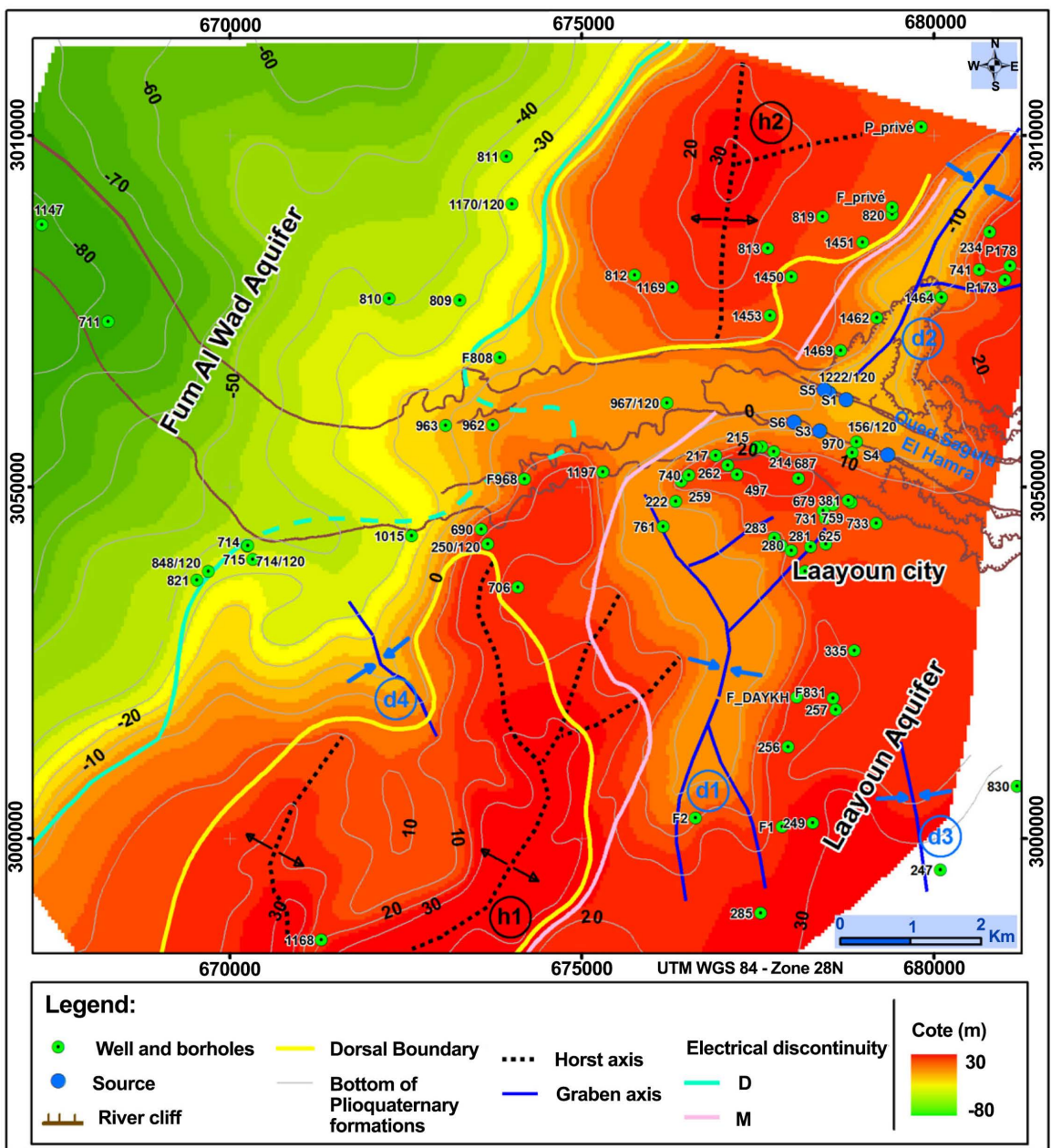

Figure 21. The wall's isohypses of the Plio-Quaternary formations map.

embedding of the conductive $\mathrm{Cm}$ substratum from east to west with a mean to low gradient in the left bank and weak in the right bank.

At the level of Oued Saguia El Hamra in the vicinity of the electrical discontinuity $\mathrm{D}$, the conductor could correspond to either Quaternary wadi quagmire bedding deposits or marly marine deposits of Miocene age. As for the infinitely conductive substratum Cs, it corresponds to the marls of late Cretaceous age.

At this level, there is a regular embedding of the roof and wall of the conductive level $\mathrm{c} 1$ and the roof of the conductive substrate Cs from east to west towards Foum El Oued.

Between the discontinuities D and $\mathrm{M}$, this map gives an idea of the roof of the intermediate level D1, which is none other than the Miocene conductive level $\mathrm{Cm}$.

This map shows the presence of high zones $\mathrm{h} 1$ and $\mathrm{h} 2$ located respectively on the left and right bank of the wadi. Their axes are oriented SW-NE more or less parallel to the discontinuity D. These high areas, correspond to horsts, are absent and seem to be eroded by Oued Saguia El Hamra.

These high areas appear to be dry areas as shown by the 1168/120,1169/120 
holes which are dry. They separate the sheet of Foum El Oued with that of Laayoune.

East of the electrical discontinuity $M$, the map reflects the shape of the roof of the conducting substratum Cs attributed to the marls of the Upper Cretaceous. The latter represents the impermeable floor of Laayoune aquifer in this sector. The latter is marked by the presence of two low zones $\mathrm{d} 1$ and $\mathrm{d} 2$. Their axes are oriented substantially SW-NE towards the sources of Oued Saguia El Hamra. These low areas correspond to grabens that will serve as drainage channels for underground water for the supply of springs that drip at the left and right banks of the wadi.

Other low areas (grabens) such as $\mathrm{d} 3$ and $\mathrm{d} 4$ are observed respectively east of the lower zone $\mathrm{d} 1$ and at the NW foot of the ridge of the left bank the discontinuity $\mathrm{M}$ and west of the electrical discontinuity $\mathrm{D}$. These low areas serve as draining water to the sources of the wadi and to the water table of Foum El Oued.

\section{Discussions and Conclusions}

In the province of Laayoune, the majority of geophysical studies in particular, geoelectric and seismic aimed to map the geological levels likely to constitute potential aquifers.

According to previous studies conducted by the DHR and ABHSHOD, the geophysical study by electrical tomography profiles was carried out on the left and right banks of Oued Saguia El Hamra to verify the existence of the dry dorsal that separates the two plains of Foum El Oued and Laayoune and the lower zones of the left and right banks which serve the drainage of brackish water towards the sources of Oued Saguia El Hamra.

Overall, this shows, in particular, the presence of the following results arising from the interpretation, reinterpretation of the soundings and the analysis of the electrical tomography profiles confronted with the lithological sections of the boreholes and the logs. These results are represented by the map of the isohypses of the wall of the Plio-Quaternary formations (Figure 21).

$\checkmark$ The appearance of the roof of the impermeable floor of Foum El Oued aquifers, in its eastern part, and Laâyoune corresponding to the Miocene marls at the level of the Foum El Oued aquifer and Miocene marls at the Upper Cretaceous level. Layers of Laayoune;

$\checkmark$ The geometry of the Plio-Quaternary aquifers of Foum El Oued (eastern part) and Laayoune (western part);

$\checkmark$ The electrical discontinuity denoted by $\mathrm{D}$ which corresponds to a change of facies of the roof of the conducting substratum $\mathrm{Cm}$ and of the lower part of its cover limiting the extension of the Foum El Oued aquifer to the east;

$\checkmark$ The electrical discontinuity marked M which would represent the eastern limit of the Oligo-Miocene tectonic pit limiting the Laayoune brackish groundwater to the west;

$\checkmark$ Other electrical discontinuities affecting the Plio-Quaternary formations 
corresponding to lateral facies variations;

$\checkmark$ At the left and right banks of Oued Saguia El Hamra, rising marly conductive substratum corresponding to the dry dorsal axis substantially SW-NE. These lifts, bordered on the west by the discontinuity $\mathrm{D}$ and on the east by the discontinuity $\mathrm{M}$, could represent the boundary between Laayoune and Foum El Oued aquifers, with the exception of Oued Saguia El Hamra and its banks or its ascents are absent;

$\checkmark$ At the level of the Oued Saguia El Hamra bed, a monoclinale drawn particularly by the roofs of the drivers $\mathrm{C} 1$ and $\mathrm{Cs}$ plunging regularly towards the catchment field of Foum El Oued. At this level, we are witnessing the absence of the ridge favoring the feeding of the Foum El Oued groundwater by the flood waters of Oued Saguia El Hamra and the contamination by sewage and brackish waters of Laayoune groundwater. This contamination has contributed to a considerable reduction in the resistivity values of the sandy past (particularly the r2 level) allowed aquifers;

$\checkmark$ Two low areas located to the south and north of Laayoune d1 and d2 and elongated along the SW-NE direction which correspond either to grabens which seem to feed respectively the sources of the left and right banks of Oued Saguia El Hamra.

At the ridges h1 and h2, the resistant level R2 corresponding to the lumachellic sandstones of the plio-Quaternary base are affected by synsedimentary faults that contributed to the fracturing and alteration of the lumachellic sandstones and subsequently to their karstification. This favored the birth of the paleodrainages within the ridge, which served to circulate water from the Laayoune groundwater to the Foum El Oued groundwater across the ridge, thus justifying the presence of the brackish groundwater of Foum El Oued. At present, the communication between the two layers is only through Oued Saguia El Hamra and when the ridge is dry.

In perspective, it is suggested to update the Foum El Oued groundwater model and establish the Laâyoune groundwater knowing that the eastern limit of the Foum El Oued groundwater, which is the subject of this study, has been well defined and the limit West is imposed by the Atlantic Ocean. The North and South remain to be determined by the realization of other geophysical studies at the Oligo-Miocene pit. This is for the sake of better optimization and management of water resources.

\section{Acknowledgements}

The authors thank the Watershed Agency of Saguia El Hamra and Oued Eddahab (ABHSHOD) for providing the necessary data. Thanks also go to AFRICA GEO-SERVICES for making hydro-geophysical equipment and processing software available for this work.

\section{Conflicts of Interest}

The authors declare no conflicts of interest regarding the publication of this paper. 


\section{References}

[1] MEM (Ministry of Energy and Mines) (2002) Geological Map to One Millionth, Laayoune Sheet. NG-28 XXIII-I. Regional Center of Geology, Laâyoune, 53 p.

[2] CGG (1961) Study Geophysical Seismic Reflection Oil in the Sedimentary Basin Laayoune-Dakhla. Report 1961/HRD, 60 p.

[3] ABHSHOD (2012) Geological Data Collection, Hydrogeological and Geophysical Previous Studies.

[4] Edoulati, N., Boutaleb, S. and Bettar, I. (2019) Hydrogeology of Different Aquifers of Laayoune-Dakhla Morocco Basin. 132.

[5] DRH (Regional Direction of Hydraulique) (2003) Geophysical Study by Electrical Surveys, Polls by Nuclear Magnetic Resonance and Seismic in the Sedimentary Basin Laayoune-Dakhla.

[6] DRH (Regional Direction of Hydraulique) (2007) Study of a Master Development Plan Integrates Water Resources (PDAIRE), in the Basin of the Sahara, Southern Morocco. Report 08/2007/HR, Mission I, Volume 1, 86 p.

[7] ABHSHOD (Basin Agency Sakia El Hamra hydraulics and Oued Ed-Dahab) (2011) Exhaustive Inventory Withdrawals of Groundwater in the Basin Sakia El Hamra and Oued Ed-Dahab. Report 02/2010/ABHSHOD, Mission I, 69 p.

[8] El Mokhtar, M., Chibout, M., Kili, M., El Mansouri, B., et al. (2018) Evaluation of Saline Intrusion in the Groundwater of Foum El Oued Province of Laayoune, Morocco. Bulletin of the Scientific Institute of Rabat, Section Earth Sciences, 40, 53-69. http://www.israbat.ac.ma/wp-content/uploads/2018/11/El_Mokhtar_et_al_Final.pdf

[9] Alia Medina, M. (1945) Caracteristicas morphograficas geológicas y la zona del northern Sahara espanol. Trabalho Instituto Ciencias National. Jose Acosta, Ser. Geol., Vol. 4, 260 p.

[10] Alia, M. (1945) Quaternario El espanol en el Sahara. Newsletter of the Sociedad Española de Historia Natural, t. XLIII, 149-163.

[11] Lecointre, G. (1952) Research on the Marine Neogene and Quaternary of the Atlantic Coast of Morocco. Notes and Memoirs Service. Geological Morocco, No. 174, Vol. III.

[12] Martinis, B. and Visintin, V. (1966) Geological Data on the Coastal Sedimentary Basin of Tarfaya (Morocco Southern). In: Reyre, D., Ed., Sedimentary Basins of the African Coast, Part 1, Association of African Geological Surveys, UNESCO, Atlantic Coast, 13-26.

[13] Ratschiller, L.K. (1970) Lithostratigraphy of the Northern Sahara Spanisch. Memoria Museo Tridentino di Scienze Naurali trento, 18, 9-78.

[14] Querol, R. (1966) Regional Geology of the Spanish Sahara. In: Reyre, Ed., Sedimentary Basins of the African Coasts, Assoc. African Geol. Survey, Paris, 27-39.

[15] Choubert, G. and Ambroggi, R. (1953) Preliminary Note on the Presence of Two Sedimentary Cycles in the Pliocene Marine Morocco. Notes Serv. Geol. Morocco, t. 7, Mem. 117, 5-53.

[16] Choubert, G., Faure, M.A. and Hottinger, L. (1966) Geological Survey of Coastal Tarfaya Basin. In the Coastal Basin of Tarfaya, t. I Stratigraphy. Notes and Memoirs of the Geological Service of Morocco, No. 175, 7-106.

[17] Ortlieb, L. (1975) Research on the Pliocene-Quaternary West Coast Saharan $\left(28^{\circ} 30^{\prime}-20^{\circ} 40^{\prime}\right.$ Lat. N). ORSTOM, Paris.

[18] Leprêtre, R., Missenard, Y., Barbarand, J., et al. (2015) Post-Rift History of the East- 
ern Central Atlantic Passive Margin: Insights from the Saharan Region of South Morocco. Journal of Geophysical Research: Solid Earth, 120, 4645-4666. https://doi.org/10.1002/2014JB011549

[19] Lecointre, G. (1963) Note on the Neogene and Quaternary Marine Spanish Sahara (Seguiet el Hamra and Rio de Oro). Notes y Comunicaciones del Instituto Geológico y Minero de Espana, No. 71.

[20] Lecointre, G. (1965) A Hypothesis on the Age of Quaternary Transgression in Mauritania. Notes and Memoirs of the Geological Service of Morocco, 25, 79-80.

[21] Lecointre, G. (1966) Neogene and Quaternary Tarfaya Coastal Basin. Notes and Memoirs of the Geological Service of Morocco, No. 175, 255-288.

Loke, M.H. and Barker, R.D. (1996) Rapid Least-Squares Inversion of Apparent Resistivity Pseudosections by a Quasi-Newton Method. Geophysical Prospecting, 44, 131-152. https://doi.org/10.1111/j.1365-2478.1996.tb00142.x

[22] DRH (Regional Direction of Hydraulique) (1998) Electrical Exploration Study of the Swallowing Part of the Oued saquia el hamra (Laayoune Region).

[23] El Mokhtar, M., Chibout, M., El Mansouri, B., et al. (2018) Modeling of the Groundwater Flow and Saltwater Intrusion in the Coastal Aquifer of Fum Al Wad, Province of Laayoune, Morocco. International Journal of Geosciences, 9, 71-92. https://doi.org/10.4236/ijg.2018.91005

[24] Astier, J.L. (1971) Geophysical Applications in Hydrogeology. Masson, Paris, 275 p.

[25] Chouteau, T. (2001) Electrical Methods, Course Notes. Ecole Polytechnique, Montreal.

[26] Telford, W.M., Geldart, L.P. and Sherif, R.E. (1990) Applied Geophysics. Cambridge University Press, Cambridge, $770 \mathrm{p}$. https://doi.org/10.1017/CBO9781139167932

[27] Bear, J. (1979) Hydraulics of Groundwater. McGraw-Hill, Inc., New York, 568 p.

[28] Reynolds, J.M. (2003) An Introduction to Applied and Environmental Geophysics. Wiley, Hoboken, 796 p.

[29] Deceuster, J. and Kaufmann, W. (2003) Implementation of 3D Electrical Resistivity Tomography Recognition of Karstified Zones, Belgium. Proceedings of the 4 th Symposium GEOFCAN, Paris, 23-24 September 2003, 137-142.

[30] Fehdi, C., et al. (2011) Detection of Sinkholes Using 2D Electrical Resistivity Imaging in the Cheria Basin (Northeast of Algeria). Arabian Journal of Geosciences, 4, 181-187. https://doi.org/10.1007/s12517-009-0117-2

[31] Dahlin, T. (1996) 2D Resistivity Surveying for Environmental and Engineering Applications. First Break, 14, 275-283. https://doi.org/10.3997/1365-2397.1996014

[32] Dahlin, T. and Bernstone, C. (1997) A Roll-Along Technique for 3D Resistivity Data Acquisition with Multi-Electrode Arrays. Proceedings SAGEEP97, Reno, 23-26 March 1997, Vol. 2, 927-935. https://doi.org/10.4133/1.2922474

[33] Dahlin, T. and Loke, M. (1998) Resolution of 2-D Resistivity Imaging Wenner as Assessed by Numerical Modeling. Journal of Applied Geophysics, 38, 237-249. https://doi.org/10.1016/S0926-9851(97)00030-X

[34] Alabjaha, B., Amraoui, F., Chibout, M. and Slimani, M. (2018) Assessment of Saltwater Contamination Extent in the Coastal Aquifers of Chaouia (Morocco) Using the Electric Recognition. Journal of Hydrology, 566, 363-373.

https://doi.org/10.1016/j.jhydrol.2018.09.003

[35] ONEP (National Office of Water Potable) (1999) Report of the Plan Study Liquid Sanitation Director of the City of Laayoune. 